\title{
Urfa'da Vakıf Kitaplar Üzerine Bir Değerlendirme
}

Mehmet Kurtoğlu*-Enver Karakeçili**

Öz

Urfa'da Osmanlı dönemi kitap ve kütüphane konusuna değinen bu makalede, üçü yeni, biri de daha önce yayınlanmış olan dört adet vakfiye üzerinden kitap ve kütüphane konusu incelenmektedir. Söz konusu incelemede Urfa'daki kitap ve kütüphane kültürü ile bunun şehrin kültürel hayatına yansıması anlatımış olup, Şeyh Ramazan Efendi Vakfi, Hacı Hafiz Mustafa bin Hasan, Dede Osman Efendi ve Hacı Kurra Efendizâde Mehmed Halid Efendi Vakıflarına ait vakıf kitaplara yer verilmiştir.

Anahtar Kelimeler: Urfa, Vakıf, Kütüphane, Vakıf Kitaplar.

\section{An Evaluation of the Waqf Books in Urfa}

\begin{abstract}
In this article that addresses the issue of books and libraries of the Ottoman period, the issue of books and libraries are examined in the light of three new waqf books and also another one which was published previously. In this work, the book and library culture in Urfa and the reflection of this culture to the general cultural life of the city is described and also it is given place to the waqf books which belongs to the Sheikh Ramadan Efendi, Al-Hajj Hafiz Mustafa bin Hasan, Dede Osman Efendi and Hacı Kurra Efendizade Mehmed Halid Efendi Waqfs.
\end{abstract}

Keywords: Urfa, waqf, library, waqf books.

* Vakıflar Genel Müdürlüğü, Müdür

** Vakıflar Genel Müdürlügüü, Musahhih 


\section{Giriş}

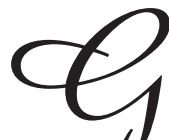
eçmişi günümüzden on iki bin yıl öncesine tarihlenen (Schmidt 2007: 102) tarihî Harran ve Edessa (Urfa) okullarıyla (üblversite) ve Ortaçağ İslam dünyasında önemli bir kültür merkezi olması münasebetiyle Urfa'nın düşünce tarihimizdeki yeri yadsınamaz. ${ }^{1}$ Tarih boyunca ilim ve kültür merkezi olan Urfa, tarihî Harran ve Urfa Üniversitesi'nde yetiştirdiği ilim adamlarıyla ve bunların düşünce tarihine kazandırmış olduğu kitap ve Risâlelerle, Yunan felsefesinin İslam âlemine taşımasında aracı rol oynamış, bundan dolayı "Doğunun Atinası" sıfatını almıştır (Çetinkaya 2013: 113).

Şehirdeki kütüphanecilik tarihinin de köklü olduğu ve M.Ö. $610^{\prime}$ Iı yıllara kadar dayandığı, Urfa ve Harran arasında yapılan kazılarda elde edilen ve Nergal'a ait olduğu sanılan arşivden anlaşılmaktadır (Yıldız 2003: 16). M.S. IV. yüzyılda Urfa'da bir okul kütüphanesinin olduğunu Ermeni tarihçi Khoreneli Moses'ten öğreniyoruz (Yıldız, 2003: 308). Hıristiyanlık döneminde ise Urfa'da halka ait belgelerin de içinde yer aldığı arşivlerin bulunduğu ve bunlar arasında Süryanice ve Eski Yunanca belgeler ile vergi kayıtlarının, tapınak annallerinin bulunduğu belirtilmektedir (Yıldız, 2003: $16 \mathrm{vd)}$.

1517 tarihinde Osmanlı hâkimiyetine giren Urfa, eğitim ve öğretim bakımından en istikrarlı dönemini yaşamıştır; birçok han, hamam, cami, medrese, kütüphane bu dönemde vakıflar aracıIığıyla yapılmış, mimarî ve kültürel anlamda şehir büyük bir gelişme göstermiştir. XVII. yüzyılda üç adet olan medrese sayısı, XIX. yüzyıla gelindiğinde on dörde yükselmiştir (Memiş 1998: 2). Vakıflar tarafindan vücuda getilen bu medreselerin on tanesinde kütüphane olduğunu 1908 tarihli Haleb Vilâyeti Salnâmesi'nden öğrenmekteyiz (Haleb Vilâyeti Salnâmesi 1327: 397). Medrese kütüphanelerinin yanında tekke ve zaviyelerin bünyesinde kütüphanelerin da bulunduğu göz önüne alındığında, şehrin küçümsenmeyecek

1 Urfa Tarihi hakkında detaylı bilgi için bkz. Ramazan Şeşen, Harran Tarihi, TDV Yay., Ankara 1993, Judahbenzion Segal, Edessa (Urfa) Kutsal Şehir, Çev. Ahmet Arslan, Illetişim yay. İstanbul 2002 ve E.R.Hayes, Urfa Akademisi, çev. Yaşar Günenç, Yaba Yay. İstanbul 2002. büyüklükte bir kitap külliyattna sahip olduğu görülmektedir.

Tarih boyunca birçok savaş ve istilaya tanıklık eden, çok sık el değiştiren Urfa, en istikrarlı ve bayındır dönemini Osmanlı hâkimiyeti altında yaşamıştır. Özellikle bu dönemde şehrin en görkemli camileri olan Hüseyin Paşa, Yusuf Paşa, Nimetullah ve Rizvaniye inşa edilmiştir. Ayrıca eğitim ve ilim hayatında vakıflar aracılığıyla büyük bir canlılık yaşanmış, birçok medrese ve kütüphane bu devirde kurulmuştur. Örneğin h. 1324/m. 1906 tarihli Haleb Vilayet Salnamesi'nde Urfa sancağındaki kütüphane sayısının on adet olduğu ve bu kütüphanelerde toplam üç bin on adet kitap bulunduğu belirtilmektedir (Kapaklı 2012: 29). Şahsi kütüphaneleri de göz önünde bulundurduğumuzda, dönemin şartları içinde kütüphane ve kitap sayısının iyi bir noktada olduğunu söyleyebiliriz.

Osmanlı dönemindeki Urfa medreselerine baktğımızda; Abbasiye Medresesi (h. 1107/m. 1695), Abdurrahman (Rahmaniye) Medresesi (17. yy.), Eyyubi Medresesi (h. 587/m. 1191), Firuz Bey Medresesi (17. yy.), Halilürrahman Medresesi (h. 813-833/m. 1410-1429), Hamis Efendi Medresesi (h. 1169/m. 1756), Hasan Padişah Medresesi (h. 866/m. 1462), Haydariye (Haydar Ağa Medresesi) (h. 1169/m. 1756), ibrahimiye (Dabbakhane Medresesi) (h. 1136/m. 1723), ìlasiye Medresesi (h. 1051/m. 1641), Kutbeddin Medresesi (h. 1192/m. 1778), Nakibzâde Usameddin İbrahim Efendi Medresesi (h. 1196/m. 1781), Rahimiye Medresesi (h. 1150/m. 1737), Rızaiye Medresesi ( h. 1193/m. 1779), Rızvaniye Medresesi (h. 1149/m. 1736), Sakıbiye Medresesi (h. 1270/m. 1854), Süleymaniye Medresesi (h. 1259/m. 1843), Şabaniye Medresesi (h. 1214/m. 1800), Şehbenderiye Medresesi (h. 1328/m. 1910), Ulu Cami Medresesi (h. 786/m. 1384), Yusuf Paşa Medresesi (h. 1121/m. 1709) ile Darü't-Ta'lim (h. 994/m. 1586) ve Darü'l-Hüffaz (Darü'l-Kurra) olmak üzere toplam yirmi medrese, iki darü'l-kurra ve darü'l-hadisin mevcut olduğu görülür. Ayrıca devrinin zengin ve şöhretli bir ismi olan Şair Sakıp Efendi'nin de, kendi adıyla anılan Sakıbiye Medresesi'ni (1863) kurduğu ve kütüphaneye şahsî kitaplarını da bağışladığı bilinmektedir (Kurtoğlu 2011: 121). 
Evliya Çelebi Seyahatnamesi'nde ise üç medrese, otuz sıbyan mektebi, üç darü'l-kurra ve darü'l-hadis olduğu yazılıdır (Kahraman-Dağlı 2010: 202). Kaynaklara baktı̆̆ımızda bahsi geçen medrese ve kütüphanelerden ayrı olarak; Şeyh Ramazan Efendi'nin Urfa'daki tekkesinde (h.1072/m. 1661), Damat Süleyman Ağa'nın (h. 1150/m. 1737) önceki asırlarda kurulan küçük kütüphanelerin bir devamı mahiyetinde bir kütüphane kurduğu bilinmektedir. Aynı şekilde Nakibzâde İbrahim Efendi'nin, medresesi içinde bir kütüphane yaptırdığı (h. 1196/m. 1781); Muhammed Fazlı Efendi'nin Dabbakhane Camii'nin kuzeyinde, babası Hacı İbrahim Efendi'nin yaptırdığı medresenin bitişiğinde bir kütüphane ile hafiz-ı kütüplerin oturmaları için iki de oda inşa ettirdiği kütüphanesinde, Maarif Nezareti Salnamesi'ne göre 1900 ve 1902 senesinde üç yüz kitap bulunduğu belirtilmektedir. 1327 senesi Haleb Salnamesi de aynı bilgeleri içermektedir. Bunun yanında XIX. asrın başlarında Urfa'da toplam beş a kütüphane olduğu belirtilmektedir (Erünsal 2008: 169-274).

Yine Mehmed Fazlı Efendi'nin tamir ettirdiği Arabizâde Camisi ve İbrahimiye Medresesi kütüphanesine, yedi adet tefsir, on beş adet hadis, on beş adet fikıh, on adet tarik-i Muhammediye, on yedi adet nahiv, dokuz adet sarf, yirmi yedi adet ilm-i meâni olmak üzere yüzün üzerinde kitap vakfetmiştir (Memiş 2011: 166). Bir görüşe göre ise yukarıda sayılan kütüphanelerden hariç dokuz kütüphane daha bulunmaktadır (Karakaş 2012: 145-155). Hacı Mustafa Hafiz veya Halilürrahman Kütüphanesi (h. 1312/m. 1895) on beş Kuran-ı Kerim ve iki yüz otuz sekiz adet kitap, Haydariye Kütüphanesi, altmış adet kitap, ìhlasiye Kütüphanesi (h. 1275/m. 1858) üç yüz adet kitap, Rahimiye Kütüphanesi (h. 1150/m. 1737) iki yüz yirmi bir adet kitap, Rızaiye Kütüphanesi (h. 1192/m. 1779) yüz adet kitap, Rızvaniye Kütüphanesi (h. 1149/m. 1736) 1905 tarihinde iki yüz, h. 1321/m. 1903 tarihinde ise yedi yüz adet kitap, Sakıbiye Kütüphanesi (h. 1286/m. 1870) yüz elli adet kitap, Süleymaniye Kütüphanesi (h. $1150 /$ m. 1737) doksan beş adet kitap, Şehbenderiye Kütüphanesi (1910) vakfiyesinde ise 10 adet Kur'an-ı Kerim, sekiz adet Tefsir-i Fahreddin Râzi, beş cilt Müşkülatü'l-Mesabih, dört cilt
İmam Buhari, dört cilt ỉhya-i Ulûm, iki cilt İmam Şarani, bir cilt Şifâ-i Şerif, bir cilt Mirkâtü'l-Fellah ve bir cilt Nüzhetü'l-Mecâlis toplam kırk iki adet kitapları bulunmaktadır (Karakaş 2012: 145-155).

Yukarıda sayılan medreselerin her birinin bir kütüphanesi olduğu vakfiyelerden anlaşılmaktadır. Ancak bu kütüphanelere ait kitaplar bugün kaybolduğundan, vakfedilen kitapları Vakıflar Genel Müdürlüğü Arşivi'nde yer alan vakfiyelerden ve şer'iyye sicillerinden öğrenmekteyiz. Adı geçen medreselerin bir kısmının yıkıldığı, kalanların ise Cumhuriyet ile birlikte kapatılmasından dolayı, bunlara ait kütüphane ve kitapların akıbeti hakkında herhangi bir bilgi bulunmamaktadır. Ancak söz konusu kitapların kimler tarafindan vakfedildiğini, içeriği ve sayısını vakfiyelerden öğrenebilmekteyiz.

\section{Vakıf, Medrese ve Kütüphaneler}

Türkçede vakıf şeklinde telaffuz edilen "vakf" kelimesi Arapça'da bir mastar olup, lügatlere göre "durdurmak", "alıkoymak" manasına gelir. Bu deyim genellikle, "terk", "emanet", "depo" fikirlerini ifade etmekte ve günlük anlamında "mukaddes bir şey, dindarlık duygusuyla insanIığın ihtiyaçlarına veya halkın ibadet hizmetlerine adanmış bir nesne" düşüncesini taşımaktadır (Yediyıldız 2003: 8). Sosyal yaşayışın üzerinde derin etkiler yapan dinî, hukukî kurumlar olarak, çoğunlukla yarış ve sevap düşüncesi ile yapılan vakıfların, toplumda sosyal dayanışmayı amaçlayan kurumlardan olduğu muhakkaktır (Kazıcı-Şeker 1982: 247). Vakfiyelere genel olarak bakıldığında, vakıf gelirlerinin tahsis edildiği sahalardan birinin de eğitim ve öğretim faaliyetlerine yönelik olduğu anlaşılır. Illköğretim müessesesi olan sıbyan mekteplerinde, medreseler ve tekkelerde eğitim hizmetlerinin vakıflar tarafindan itina ile yürütüldüğünü görmekteyiz. İslam dünyasında darü'l-hadis, darü'l-kurra ve medreselerin büyük bir kısmı da vakıf olarak vücuda getirilmiş ve bütün masrafları vakıflar tarafindan karşılanmıştır. Bu medreselerle ilgili vakfiyelerde, ders verecek öğretim kadrosunun (müderris, muîd, danişmend, muhaddis, muallim-i feraiz, muallim-i hat, vaiz, şeyhu'l-kurra, vs.), kütüphanesi olanlar için hafizü'l-kütüb ve diğer hizmetlilerin tayinleri, okutulacak dersler (ulûm-i akliye, ulûm-i nakli- 
ye, ulûm-i şer'iyye ulûm-i âliye, ulûm-ı nafia) için ödenecek ücretler, kısaca medreselerin iç işleyişleri hakkında çok dikkatçekici ve kıymetli bilgiler bulunmaktadır. Vakıflar sayesinde medreseler tam Muhtâriyete sahip müesseseler haline gelmiştir. (Yediyıldız 1989: 44-45)

Osmanlı eğitim sistemine baktı̆̆ımızda Osmanlı medreselerinin kurulduğu Orhan Gazi devrinden itibaren okutulan derslerin daha ziyade dinî ilimlere tahsis edildiği, bu sebeple medrese eğitiminde esas tutulan tefsir, hadis ve fikıh gibi ilimler okutulduğu ve bu ilimlere yüksek ilim manasında ulûm-i âliye (عليه (علوم) denildiği bilinmektedir. Ayrıca mezkûr ilimleri öğrenmeye vasıta olan mantık, belagat, sarf ve nahiv ilimlerine ise ulûm-i âliye (آليه علوم) (âlet ilimleri) denildiği ve bunun yanında cüz'iyât veya koltuk dersleri denilen ve XVI. asrın sonlarında kaldırıldığı iddia edilen matematik, hendese, he'yet (astronomi) ve felsefe ilimlerinin de belli bir süre medreselerde okutulduğu kaynaklarda geçmektedir (Akgündüz 2012: 71).

Ayrıca medrese vakfiyelerinde, belirtilen pek çok husus arasında orada okutulacak dersler hakkında şartlar konulduğuna da rastlanmaktadır. Örneğin, Niğde'deki Karamanoğlu Ali Bey Medresesi'nin vakfiyesinde, medresede şer'î ve edebî ilimlerin, fikıh ve usul-ü fikıhın yanı sıra on beş şer'î ilimin okutulacağı, Konya Karatay Medresesi vakfiyesinde, ders verecek müderrisin özellikleri sayılırken şeriat, hadis, tefsir, usul, furû' ve hilaf ilimlerinde uzman olmasının istenmesi, burada okutulacak dersler hakkında fikir vermesi bağlamında bir örnektir. Sultan II. Murad’ın Edirne'de yaptırdığı Dârü'l-Hadîs'in vakfiyesinde de; "şu da şartımdır ki, müderris medresede katiyen felsefî ilimlerle iştigal etmeyecektir. Orada müderris ders günlerinde hadis ilmi ve onunla ilgili diğer dersleri öğretecek ve onun öğrettiklerinden iadesi gerekenleri muîd tekrar edecektir" diye yazmaktadır (Ergün 1996: 1).

\section{Urfa'da Medreseler, Vakıf Kitap ve Kütüphaneleri}

Birçok İslâm ülkesinde olduğu gibi, Osmanlı Devleti'nde de, başta sultan ve sadrazamlar olmak üzere hayırsever kimseler tarafindan cami ve medrese etrafinda veya özel surette yapılan binalarda ya da külliyelerde pek çok kütüphane kurulmuş, bunların bakımı ve yönetimi için vakıflar tesis edilmiştir. Birer kültür müessesesi olan kütüphaneler, yüzyıllarca kurucuların vakfiyelerinde koydukları şartlar doğrultusunda mütevelliler tarafindan yönetilmiştir (Öztürk 1995: 391). Arapça bir kelime olan medrese, "ders okunan yer" veya "ders yapılan mekân" anlamına gelmektedir. İslamiyet'in ilk dönemlerinden Osmanlı dönemine kadar medreseler birer eğitim yuvası olarak hizmet vermişlerdir. Bunun yanında faal kültür ve propaganda merkezleri olan tekke ve zaviyeler (Barkan 1963: 241) ile İslamiyet'in ilk dönemlerinde ibadetin yanında öğretim faaliyetlerinin sürdürüldüğü mescitler (Erünsal, 2008: 2) ve muhtelif öğretilerin yanında vaaz ve Kur'an öğretilerinin yapıldığı yerler olan camiler de birer eğitim-öğretim merkezleri olarak değerlendirilebilir. Bahsi geçen yerlerde görev alan hizmetlilerin ücretleri, faaliyetin gerçekleştirileceği fiziki mekânlar ve iaşe giderleri vakıflar tarafindan karşılanmıştır. Bundan dolayıdır ki vakıf kavramının medeniyet tasavvurumuzda yeri ve önemi yadsınamayacak derecede büyüktür. Sadece eğitim değil, ekonomi, istihdam, şehirlerin mamur hale getirilmesi, ibadet için dinî yapıların inşası, yoksullara yemek yedirilmesi, hastane yapılması gibi sosyal hayatın birçok alanında vakıfların etkin bir şekilde faaliyet gösterdiği anlaşılmaktadır.

Medeniyet ve kültür hayatımızda vakıf medreseleri ve kütüphaneler de önemli bir yer tutmaktadır. Tarih boyunca İslam dünyasında, kitap ve kütüphanelere büyük önem verilmiş, adeta bir kitap medeniyeti kurulmuştur. İlk dönemlerde kitap ve kütüphanelerin, daha çok dar bir alanda bireysel çabalarla şekillendiğini, daha sonraları ise, bunun kişisel çabalardan sıyrılarak kurumsallaştı̆̆ görülmektedir. İslam âleminde ilk kütüphanelerin, Kur'an-ı Kerim ve hadislerin etrafinda yoğun bir telif faaliyetinin başladığı Emeviler döneminde (661-750) aynı zamanda birer okul olarak da görev yapan mescitlerde ortaya çıktığı sanılmaktadır. Kaynaklardan öğrendiğimize göre bu devrede bazı âlimlerin de evlerinde önemli sayılabilecek sayıda kitaptan oluşan kütüphaneleri vardı. Yine İslam dünyasında kütüphanelerin h. I-II/m. VII.-VIII asırlarda daha çok Beytü'I-Hikme veya Dârü'l-Hikme şeklinde adlandırılan araştırma kurumlarında yer aldığını görmekteyiz. 
Bu kurumlar h. IV/m. X. asrın ortalarına kadar varlıklarını sürdürmüşler ve bu asrın sonlarına doğru, yerlerini dârü'l-ilmlere bırakmışlardır (Erünsal 2008: 3). Özellikle Fatih'in İstanbul'u fethetmesiyle birlikte, burada büyük medrese ve kütüphanelerin kurulduğunu ve bundan ilhamla imparatorluğun diğer şehirlerinde de medrese ve kütüphanelerin yaygınlaştı̆̆ını kaynaklardan öğrenmekteyiz (Erünsal, 2008: 91).

\section{Vakfedilen Kitaplar}

Urfa'da medrese, cami ve tekke kütüphanelerine vakfedilen kitaplara baktığımızda, Osmanlı eğitim sisteminde okutulan Kur'an, hadis, tefsir, fikıh, tasavvuf ve fen ilimleri kitaplarının yer aldığını görmekteyiz. Zira Osmanlı eğitim sisteminde dini ilimlerin ağırıklı olduğu, yabancı dil bağlamında da Arapça ve Farsçanın öğretildiği bilinmektedir. Urfa medreselerinden mezun olup, İngilizce, özellikle Fransızca gibi dilleri öğrenenlerin, bunları kendi çabasıyla öğrendiği bilinmektedir. Örneğin Urfa Müftüsü Hasan Açanal Efendi, Fransızcayı Urfa'da Süryani bir papazdan öğrendiğini belirtmiştir.

Urfa'daki güçlü tasavvufî gelenekten dolayı, vakfedilen kitaplar arasında İslam tasavvufunun önemli kaynak eserlerinin yer aldığı görülmektedir. Yine bu vakfiyelerden ilme ve okumaya önem verildiği, kitap vakfederken, kitabın kaybolmaması için rehinsiz, hatta şeyh ve müderrislerin tasarrufu dışında kimseye verilmemesinin şart koşulması bunu göstermektedir. Şehirdeki medrese, kütüphane ve vakfedilen kitap sayısı, şehrin o dönemde içinde bulunduğu eğitim, kültür ve sosyal hayat hakkında bize bilgiler vermektedir. Zira gerek kitap çeşidi ve sayısı, gerek vakfedilen kitapların içeriği incelendiğinde, aynı zamanda şehirdeki fikir ve sanat hayat hakkında bilgilere ulaşmak mümkündür. Kitapların dinî ve tasavvufî içerikte olması bugün de şehirde güçlü bir şekilde devam eden tasavvufî damarı işaret etmektedir. Örneğin el-Hâc Hafiz Mustafa bin Hasan kütüphanesine baktı̆ımızda, on beş cilt Kur'an-ı Kerim ve iki yüz otuz sekizden fazla dinî ve tasavvufi mahiyette kitap vakfedildiğini görürüz (UŞS, nr.219: 557).

Vakıf arşivi ve şer'iyye sicillerinde yaptı̆ı̆ız araştırma neticesinde, vakıf kütüphaneleri açı- sından daha önce bilinmeyen Urfa kültür ve eğitim hayatının aydınlatılmasına katkı sağlayacak üç adet vakfiyeye ulaşılmıştır. Urfa'da vakfedilen kitaplar olarak seçilen üç adet vakfiye ve daha önce ele alınan "el-Hâc Hafiz Mustafa bin Hasan Vakf"na² ait vakfiyede belirtilen kitap isimleri, vâkıfları ve vakfiye şartlarına bakıldığında dönemin eğitim, bilim ve dünya görüşü hakkında bilgilere ulaşılabilmektedir. Ele alınan bu dört vakfiyeye bakıldığında, vâkıfların, vakfedilen bu kitapların medresede ders kitabı olarak okutulmasını şart koşmadıklarını görmekteyiz. Zira bu durum Urfa'da eğitim ve öğretim faaliyetlerinin sadece medrese bünyesinde yapılmadığı, aynı zamanda tekke ve zaviyelerde de yürütüldüğüne dair bir işarettir. Bu vakıfların haricinde Halilürrahman Zaviyesi'nde, İbrahim Halebî'nin öğretisi/dersiyesinin okutulması, muhaddis görevine atamaların yapılması, tekke ve zaviyelerde tarikat şeyhlerinin mensup oldukları tarikata ilişkin öğretileri buralarda öğretmeleri yukarıda işaret edilen uygulamaya örnek olarak gösterilebilir (Karakeçili 2015: 66 vd). Zikredilen üç adet vakıf kitaplarını, Şeyh Ramazan Efendi, Dede Osman Efendi, Hacı Kurra Efendizâde Mehmed Halid ve Mehmed Salih Efendiler vakfetmiştir. Bu üç vakfiyenin yanında daha önce yayınlanmış olan elHâc Hafiz Mustafa bin Hasan vakfina ait kitaplara da yer verilmiştir. Vakfedilen bu kitapların hiç biri medresede okutulmak veya buraya konulmak için vakfedilmemiştir. Dört adet vakfiyeden üçüne ait vakfiyelerin tahlilinden, vakıf kurucularının görev yaptıkları tekkelere konulmak üzere kitap vakfettiği, diğer vakfiyede ise kitapların aile efradı tarafindan kullanılması için vakfedildiği anlaşı|maktadır.

\section{Şeyh Ramazan Efendi Vakfi ve Kitapları}

Asıl adı Ramazan, mahlası Şani'dir. Urfa'nın bilinen en eski şairi olan Şeyh Ramazan 1631 yılında Urfa'da doğmuştur (Alpay 1986: 213). Halveti tarikatına girmiş ve şeyhlik mertebesine erişmiştir (Karakaş 1996: 148). 1693 yılında vefat etmiştir. Türbesi Beykapısı Buğday Pazarı'nın kuzey tarafindadır. Tertip edilmiş fakat basılmamış bir Dîvânı olduğu söylenmektedir (Alpay 1986: 213).

2 Bu vakfiye kitap isimleriyle beraber Mahmut Karakaş tarafindan yayınlanmıştır. (bkz. Mahmut Karakaş, Cumhuriyet Öncesi Şanlıurfa'da Kültür ve Eğitim, Şanlıurfa Valiliği Yay., Konya 2012. 


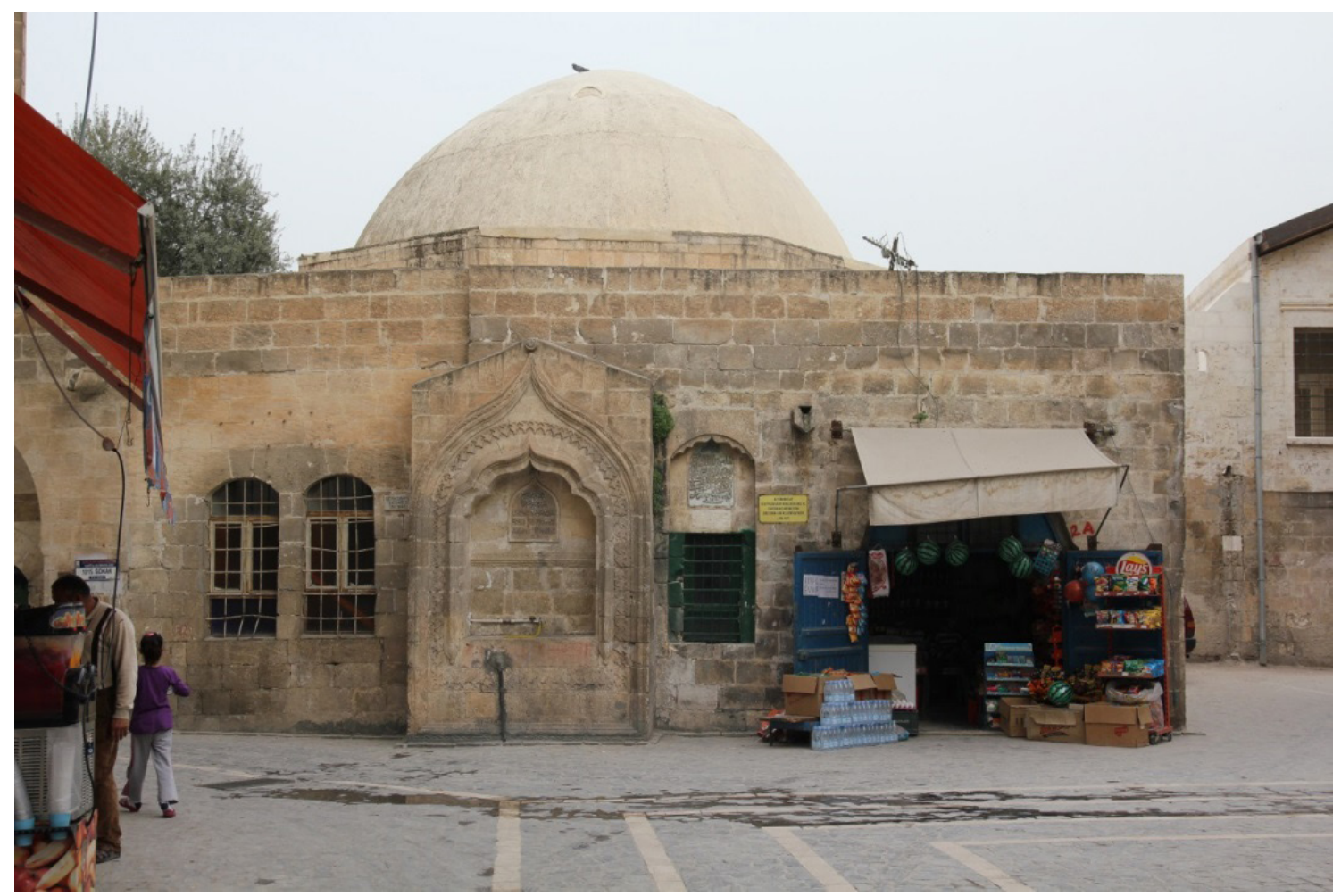

Resim 1. Tekye-i Cedîde (Bugünkü adıyla Şeyh Safvet Tekkesi) (Fotoğraf: Yasin Küçük Arşivi)

Şeyh Ramazan Efendi Rebiu'l-ahir 1069/ Ocak 1659 tarihli vakfiyesinde bina eylediğini belirttiği "Tekye-i Cedîde", Elli Sekiz Meydanı diye bilinen ve kayıtlarda Kurtuluş Mahallesi adıyla geçen mahalledeki Halvetiye tekkesidir. Bu tekke günümüzde Şeyh Safvet Tekkesi olarak bilinmektedir. Tekke bugünkü adını Halvetiye şeyhi olan Şeyh Safvet Efendi'den almaktadır. Şeyh Safvet Efendi, Dârü'l-Hikmeti'l-İslâmiye'de görev yapmış, Meclis-i Mebusan ve Cumhuriyet döneminde iki dönem mebusluk yapmıştır. Elli iki arkadaşıyla hilafetin kaldırılması için önerge vermiş bir zattrr. Tekkenin ismi onunla şöhret bulmuştur (bkz. Özdemir 2014).

Şeyh Ramazan Şani'nin yaptırmış olduğu Tekye-i Cedîde'nin şeyhi, babası Hacı Gazi Halife'dir. Bu zatn tarikat silsilesinde ismi, "Kıdvetü erbâbü't-Tarîka Mevlânâ el-Hâc Gazi Şani Halife" şeklinde geçmektedir. Ramazan Şani, yaptırdı̆̆ı tekkeye yine kendi adına bir vakıf tesis etmiş, bu vakfin vakfiyesinde tekkenin mütevellisine, şeyhine, Kur'an-ı Kerim hocasına vakfindan ücretlerinin verileceğini belirtmiştir (Karakaş 1996: 149). Vâkıf Rebiu'l-ahir 1069/Aralık1658-Ocak 1659 tarihli vakfiyesinde "... bir salih ehl-i Kur'ân ve sâhib-i hilm-i kâmilu'l-îmân ve câmi'u'l-ilm kimesne tekye-i mezbûrede mu'allim olub etfâl-i hâlisatü'l-bâle ve sıbyân-ı sâfiyyü'l-cenâne ta'lîm-i Kur'ân-ı azîmü'ş-şân eyleye ve vazîfe-i yevmiyesi üç akçe ola..." ( VGMA, Defter 586: 175/168) ifadelerinden dinî ilimler yanında diğer ilimlere de vâkıf olan salih bir kimsenin, tekkede akıl baliğ ve sıbyan olanlara Kur'an- Kerim öğretmek üzere muallim olarak görev yapmasını ve buna günlük üç akçe verilmesinin şart koşulduğu anlaşıımaktadır. Yukarıda değinildiği üzere bu tekkenin gerek vakfedilen kitaplar ve gerekse görevlendirilen muallimden de anlaşılacağı üzere, bir eğitim kurumu mahiyetinde işlev gördüğü söylenilebilir.

Vakfiye tarihinden iki yıl sonra yapılan vakıf tahririnde pek de olağan olmayan bir şekilde vakfa ait kitap listesinin kaydedildiği görülmektedir. Söz konusu Muharrem 1072/ Ağustos 1661 tarihli tahrirde "...fukarâ-yı Tarîkat-i Halvetiye içün kendü mâlından Bâbü'l-Emir Mahallesi'nde arz-ı hâlîye üzere binâ eylediği Tekye-i Cedîde'ye kendü emlâk ve akârâtindan vakfeylediği kütüb-i mu'tebere ve sâir akârât-ı mevkûfe-i mu'ammereyi beyân eder..."(TKGMA, nr. 574, s.2) ifa- 
deleriyle vâkıf bina eylediği mezkûr tekkeye konulmak üzere otuz dört ciltlik kitap vakfetmiştir ${ }^{3}$ (Bkz. Ek-2). Vâkıfin vakfedilen bu kitapların tekkede okutulmasını ve dışarıya çıkarılmamasını şart koştuğunu, "Tekye-i mezbûrede okuyub okutalar. Tekyeden taşra çıkmamak üzere şart olunmuşdur" ifadelerinden anlamaktayız. Ayrıca vakfedilen bu kitaplar için özel bir mekân tahsis edilmediği, tekkenin herhangi bir odasına konulmak üzere gelen tarikat mensuplarının istifadesine sunulduğu vakfiyeden anlaşılmaktadır.

\section{Hacı Hafiz Mustafa bin Hasan Vakfina Ait Kitaplar}

Devrinin büyük din âlimi ve hafizlarından olan Hacı Mustafa Hafiz Efendi h. 1245/m. 1829 yıIında Urfa'da doğmuştur. Zamanın meşhur âlimi Rızvaniye Medresesi müderrislerinden İbrahim Efendi'den ders almıştır. Yıllarca Halilürrahman Medresesi'nde ders vermiş, birçok öğrenci yetiştirmiştir. 1908 yılında vefat eden Hacı Hafiz Mustafa Efendi, Halilürrahman Cami mezarlığına defnedilmiştir. Yetiştirdiği talebeleri arasında ünlü Matematikçi Celal Saraç'ın babası Abbas Vasık Efendi (1859-1922), Buluntu Hoca Abdurrahman Efendi (1865-1968), Miftahizâde Hasan Efendi (1873-1953) ve Müftü Şeyh Müslüm Efendi (ö.1937) gibi âlimler bulunmaktadır. Nakşibendi halifesi olan Hacı Mustafa Efendi, Halilürrahman Zaviyesi'nde post-nişinlik yapmıştır (VGMA, Defter 2150-1, 353/376).

Ayn-ı Halilürrahman Zaviyesi'nde şeyhlik görevini ifâ eden ve Urfa'nın meşhur âlimlerinden Buluntu Hoca'nın pîri olan el-Hâc Hafiz Mustafa bin Hasan 25 Ramazan 1312/22 Mart 1895 tarihli vakfiyesinde Halilrrahman Zaviyesi'nde müderrris bulunan kişinin tasarrufunda bulunmak ve dışarıya rehinsiz olarak verilmemek üzere çok sayıda kitap vakfetmiştir (UŞS, nr. 219: 557). 238 cildi bulan bu kitapların tasarrufuyla ilgili olarak vâkıf 24 Zilhicce 1320/24 Mart 1903 tarihli zeyl vakfiyesiyle bazı değişikler yapmıştır. Bu kitapların sayısı ile ilgili olarak h.1326/m. 1908 tarihli Haleb Salnamesi'nde ise Halilürrahman Kütüp-

3 Bu rakam vâkıf tarafindan 33 adet olarak zikredilmiş olup Mushaf-ı Şerif ile beraber 36 adet kitap olduğu beyân edilmiştir (TKGMA, nr. 574, s.2). hanesi'nde 150 adet kitap bulunduğu belirtilmektedir (Memiş 1998: 30).

Vakıf kurucusunun 25 Ramazan 1312/22 Mart 1895 tarihli vakfiyesindeki, “...Emmâ ba'd, hâdim-i makâm-ı ceddü'l-enbiyâ el-HâcHâc Hâfiz Mustafa bin Hasan meclis-i şer'-i şerîf-i şâmihü'l-evtâdda ahkâm-ı vakfi tescîl içün mütevellî ta'yîn itdiği Suruç nâ'ibi Mahmud Efendi mahzarında... bi'l-iştirâ silk-i milkimden tanzîm olan emlâkimden kütüb-ü nefîsemin serlevhâ-i a'yârı on beş cild Kelâm-ı Kadîm ile zeyl-i vakıfda esâmî ve mikdârı mukâyyed kitâblarımı ve... büyût-ı adîdeyi müştemil bir adet menzilimi ve el-an ikâmet ${ }^{4}$ etmekde bulunduğum Zaviye-i Ceddü'l-Enbiyâ'da... tefrî̧s olunan iki halı ve bir büyük kilim ve on yedi kendir yasdık ve beş köşe döşeği ve bir mak'ad döşeği ve bir soğuk şerbet takımı ve bir takım çay ve kahve takımları enfes-i emvâlimden ifrâz... vakf ve habs idüb şöyle şart eyledim ki... Fî yevmi'l-hamîs ve'l-ışrîn min-şehr-i Ramazâni'l-mübârek fî sene 1312." ifadelerinden vakfedilen kitapların arasında on beş ciltlik Kur'an-ı Kerim'in olduğu ve kitaplardan başka halı, kilim, yastık, kahve ve çay takımları vesaireyi de vakfettiği anlaşımaktadır (UŞS, nr. 219: 557). Halilürrahman Zaviyesi'nde şeyh ve ferrâşlık ${ }^{5}$ görevini ifâ eden el-Hâc Hafiz Mustafa bin Hasan'ın zikredilen vakfiye ve zeylinde bu kitapların nereye konulacağı ile ilgili olarak bir şart koymadığı anlaşılmakta olup, Ayn-ı Halilürrahman Zaviyesi'nde şeyhe kendisine tahsis edilen binaya (bkz. Resim-1) konulmuş olması lazım gelir. Zira vakıf kurucusu kitabın yanında ikâmet ettiği odada muhtelif bazı eşyalarını da vakfettiğini belirttiğinden bahsi geçen kitapların da kendisine tahsis

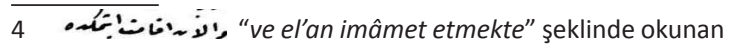
bu kelimenin, (bkz; Mahmut Karakaş, Cumhuriyet Öncesi Şanlıurfa'da Kültür ve Eğitim, Şanlıurfa Valiliği Yay., Konya 2012, s. 145 ; Mehmet Memiş, Şanlıurfa Medreseleri, Marmara Üniversitesi Sosyal Bilimler Enstitüsü, Yayımlanmamış Doktora Tezi, İstanbul 1998, s.30.) doğru okunuşu "ve el'ân ikâmet etmekte" şeklindedir.

5 Bu iki görevin, şeyh ve ferraşlık, tek kişiye verilmesi, söz konusu Halilürrahman Zaviyesi için bazı köylerin öşür gelirlerini vakfeden Kanuni Sultan Süleyman'ın 1541 tarihli vakfiyesinin şart gereği olduğu anlaşılmaktadır (VGMA, Defter 2150/2: 6). Şeyhlik görevini yapan kişinin aynı zamanda ferraşıık görevini de yapmasının şart koşulması, şeyhlik mertebesindeki birinin temizlik vs. işlerle vazifelendirilmesi nefsî ve tasavvufi bir terbiye metodu olarak telakki edilebilir. 


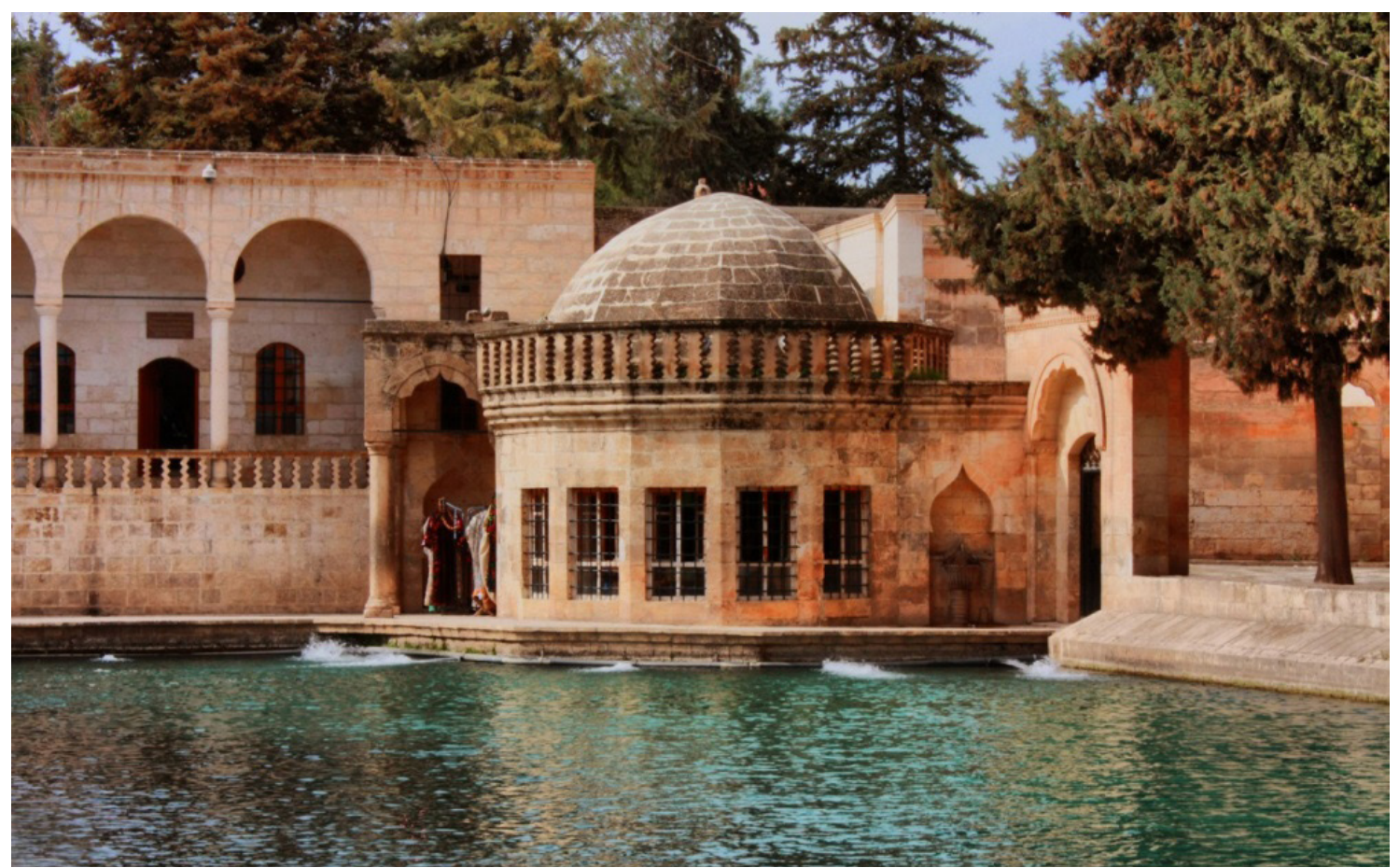

Resim 2. Ayn-ı Halilürrahman Zaviyesi'ne ait şeyh odası (Fotoğraf: Yasin Küçük Arşivi)

edilen bu odaya konulmuş olduğu ve buranın bir kütüphane mahiyetine geldiğini söyleyebiliriz.

Vakfa ait 24 Zilhicce 1320/24 Mart 1903 tarihli zeyl vakfiyede ise, vakıf kurucusu Ayn-ı Halilürrahman Vakfi'nın vakfiyesinde tedris şart bulunmadığından müderristen maksadının vefatından sonra ilim ve tedris ile meşgul olan kimse olmadığından kendisinden sonra icazetli talebesi olan Buluntu el-Hâc Ahmed Efendizâde Abdurrahman Efendi'ye verilmesi ve bu şahsın eğer zaviyeadı geçen zaviyeye şeyhlik ve post-nişinliğe atanırsa kendi hücresinde ders ve devir ile meşgul olup, layıkıyla görevini ifâ etmek şartıyla bu kitapların yine Abdurrahman Efendi (Buluntu Hoca) yedinde (elinde) olmasını ve eğer mezkûr zaviyede bulunmaz ise her nerede olursa olsun ehil olmayanın eline geçmemesi için yine Abdurrahman Efendi'ye vakfettiği anlaşılmaktadır (UŞS, nr. 219: 557). El-Hâc Hafiz Mustafa bin Hasan'ın vefat etmesiyle Abdurrahman Efendi'nin Ayn-ı Halilürrahman Zaviyesi'nde meşîhat görevine 14 Zi'l-ka'de 1328/17 Kasım 1910 tarihinde atandığı ve tarafina berat verildiği görülmektedir (VGMA, Defter 2150/1: 293/309). Bu atamadan sonra meşihat görevine atama yapılmadığı ve dolayısıyla Abdurrahman Efendi'ye vakfedilen bu ki- tapların, onun görevinin sona ermesinden sonra, akıbeti hakkında bir bilgi bulunmamaktadır.

\section{Dede Osman Efendi'nin Vakfettiği Kitaplar}

Devrinin en büyük Kadiri şeyhi, büyük mutasavvıf Dede Osman Avni Hazretleri'nin doğum tarihi kesin olarak bilinmemektedir. Vefat tarihi mezar taşında h. 1300/m. 1883 olarak geçmektedir. Kabri Mevlûd-i Halil Cami içindeki kendi türbesindedir. Dede Osman Avni Hazretleri Mevlûd-i Halilürrahman Zaviyesi şeyhlerinden biri olup, görev yaptğı bu zaviyeye konulmak üzere h. $1301^{6} / \mathrm{m}$. 18831884 tarihindekırk cilt kitap vakfetmiştir (UŞS, nr. 225: 599). Dede Osman Efendi'nin h. 1300/m. 1883 tarihinde vefat ettiği göz önüne alındığında, düzenlenen bu kitap vakfinın kendisi tarafindan değil, mahkemece h. 1301/m. 1884 yılında tanzim edildiği anlaşılmaktadır. Ayrıca vakfiyede kitapların nasıl kullanılacağı -zaviyeye konulmak şart haricinde- kimlerin istifadesine sunulacağı gibi şartlar bulunmaması da bu ihtimali kuvvetlendirmektedir.

6 Bahsi geçen vakfiyede tarih verilmediğinden vakfiyeden önceki belgede yer alan h. 1301 tarihi dikkate alınarak vakfiye tarihinin de aynı tarih olabileceği değerlendirildiğinden bu tarih verilmiştir 
Ona ait eşyalar caminin ziyaret girişinde sergilenmektedir. Kadiri tarikatnnda önemli bir yere sahip olan Dede Osman Efendi, Anadolu'ya Kadiriliğin yayılmasında önemli rol oynamıştır. Otuz yaşında şeyhliğe başladığı ve yüz yaş civarında vefat ettiği sanılmaktadır (Karakaş 1996: 147). Dede Osman Efendi'nin Mevlûd-i Halilürrahman Zaviyesi'ne hangi tarihte atandığı kesin olarak bilinmemekle beraber, 6 Receb 1303/10 Nisan 1886 tarihli belgede senevî bin beş yüz kuruş maaş ile süregelen teamül üzere beratsız olarak zaviyenin meşihat cihetinin yetmiş seneden beri Tarikat-ı Aliye-i Kadiriye'den Dede Osman Efendi'nin uhdesinde olduğu ve vefatyla Hafiz Halil bin Müslim Efendi'ye tevcih edildiği belirtilmiştir (BOA, Ev. Mkt.1352/64). Söz konusu belgede "yetmiş seneden beri" denildiğinden Dede Osman Efendi'nin zaviyedeki meşihat görevine h. 1231/m. 1815-1816 yılında atanmış olması lazım gelir. Dede Osman Efendi'den önce şeyhlik görevine, günlük on akçe ile görev yapan Mustafa'nın ölümüyle Şeyh Hacı Mehmed'in h. 1168/m. 1754-55 tarihinde atandığı anlaşılmaktadır (VGMA, Defter 1090: 119). Şeyh Hacı Mehmed'in ferâğıyla bu defa günlük on akçe ile Mevlûd-i Halilürrahman Zaviyesi'nde seccâde-nişîn olarak kaydedilen görevin, oğlu Seyyid Mustafa'ya 27 Zi'l-ka'de 1188/5 Ağustos 1774 tarihinde tevcih edildiği (VGMA, Defter 1084: 107) görülmektedir ki; bu da Dede Osman Efendi'nin zaviyenin kurucusu ve ilk şeyhi olduğu yönündeki görüşlere (Tenik 2011: 203) katılmamızı engellemektedir.

Görev yaptğ̆ zaviyeye konulmak üzere kırk cilt kitap (bkz.Tablo-3) vakfettiği belirtilen Dede Osman Efendi'nin bu kitapları zaviyede bulunan derviş ve müritlerin istifade etmesi için bağışladığı değerlendirilebilir. Kadiri tarikat hulefasından olduğunu bildiğimiz Dede Osman Efendi'nin (BOA, EV.Mkt.1352/64.) zaviyede derviş ve müritleri tasavvuf vetarikat gibi konularda eğittiği, vakfedilen kitapların içeriğinden anlaşılmaktadır (bkz. Ek-3).

Zaviyede bulunan hücrelerden birine konulmak üzere vakfedildiği anlaşılan bu kitaplar için bir kütüphane binasının tahsis edildiğiyle ilgili olarak herhangi bilgi mevcut değildir. Ancak bu kitapların bugün dahi bir kısmı Mevlûd-i Halilürrahman Camii'nin ziyaret girişi yanındaki bir odada sergilendiği bilinmektedir (Tenik 2002; 108).

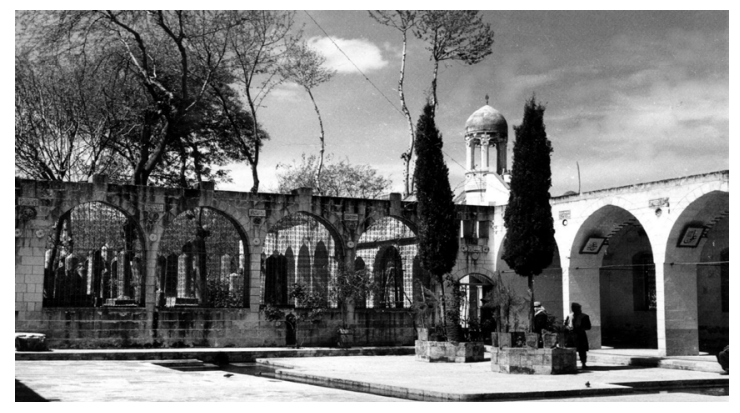

Resim 3. Mevlûd-i Halilu'r-Rahman Külliyesi (Fotoğraf: Yasin Küçük Arşivi)

\section{Hacı Kurra Efendizâde Mehmed Halid ve Mehmed Salih Efendilerin Vakfettiği Kitaplar}

1823 yılında Urfa'nın Mevlûd-i Halil Mahallesi'nde dünyaya gelen Mehmed Halid Efendi, Kurrazâde ailesine mensuptur. Hasan Padişah Medresesi'nden mezun olmuştur. Çok dindar olduğu için Mevlânâ Halid diye tanınmıştır. Kur'an'ı hıfzetmiş, "Kıraât-ı Seb'a" ile okumaya muvaffak olmuştur (Alpay 1986: 77). Şair de olan Mehmed Halid Efendi, Kadiri, Rufai ve Nakşibendi tarikato halifesidir. Bu gibi çok tarikat şeyhlerine "Camiü'l-Turuk" denilmektedir. Nakşibendi tarikatnın Halidiye kolunun Ziyaiye ve Bekriye kolundan gelmektedir (Karakaş 1996: 87). 1891 yılında vefat etmiş, Mevlûd-i Halil mezarlığına defnedilmiştir. Mezar taşında "Şuâradan Mevlânâ Kurrazâde Halid Rebiü'l-ahir sene 1311" yazılıdır (Alpay 1986: 77).

Tahtemur Mahallesi sakinlerinden olan Mehmed Halid Efendi ve kardeşi Mehmed Salih Efendilere ait Muharrem1293/Ocak 1876 tarihli vakfiyede “...zeyl-i kitâbda mezkûr kütüb-i müteferrik-i şerî̀ dahi ber-minvâl-i sâbık ilâmâ- tenâselu ve te‘âkabu evlâd-ı evlâd-ı evlâd-ı evlâd-ı evlâdı zükûrumuzun a'lem ve utekâsına ve ba'de'l-inkırâz alâ-vechi's-sâbık ashâb-ı ferâiz ve asabe ve zevi'l-erhâm cihetinden akrabâmızın a'lem ve utekâsına ve ba'de'linkırâz Harameyni'ş-Şerifeyn kütübhânelerine vaz' olunub talebe-i ulûm müstefid olmak üzere vakf eyledik..." (UŞS, nr. 211: 1190) ifadelerinden, adı geçen 126 kitabın (bkz. Ek-4) yukarıda isimleri ve vâkıflarının şartları 


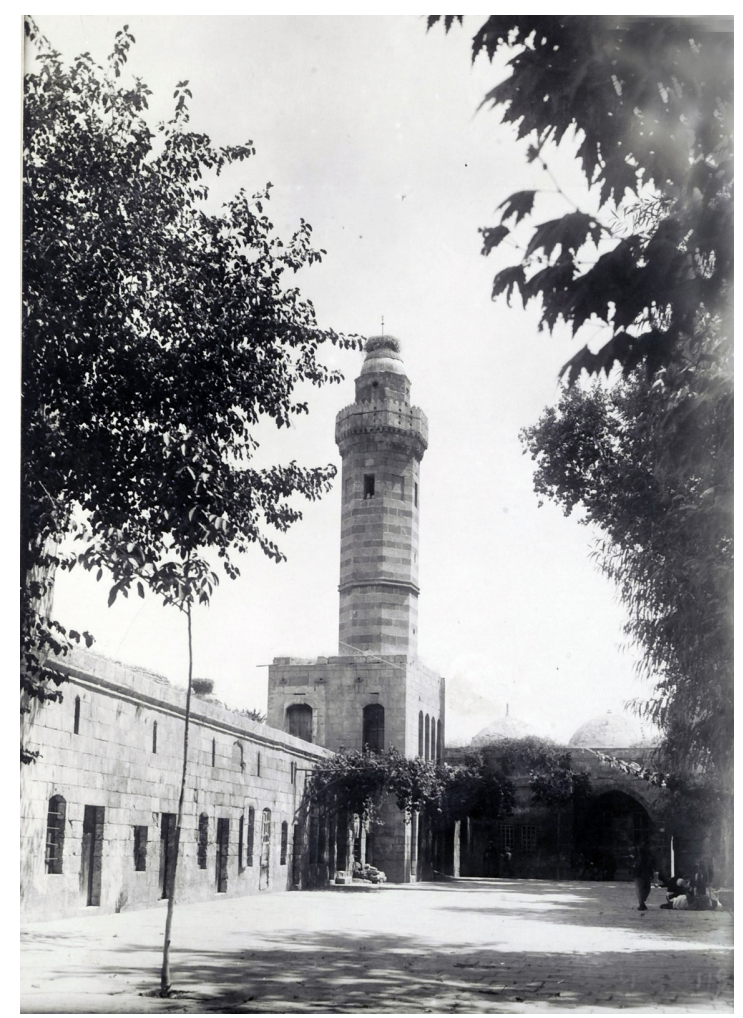

Resim 3. Mevlûd-i Halilu'r-Rahman Külliyesi (Fotoğraf: Yasin Küçük Arşivi)

belirtilen diğer üç vakıftan farklı olarak tasarruf hakkı ile ilgili olarak vakıf kurucularının "daha iyi bilen ve günah işlemekten korkan" nesilden nesile erkek evlatlarına inkırazında ise aynı vasıflara sahip akrabalarına ve bunların dahi inkırazında bu kitapların Harameyn-i'ş-Şerifeyn kütüphanelerine konulmasını şart koştukları anlaşılmaktadır. Yani bu kitapların istifadesi öncelikle kendi nesillerine bırakılmış olup, nesillerinin inkırazında ise kitapların şehirde bırakılmaması ve Harameyni'ş-Şerifeyn kütüphanelerine gönderilmesi şart konulmuştur. Bu şartların dikkat çekici tarafi vakfedilenin menkul ve gayrimenkul olmamasına karşın, böyle düşünülüp kitapların bütün toplumun istifadesine sunulmayıp ailenin istifadesine sunulmasıdır. Zira vakıf kurucuları genel itibariyle kar getiren menkul ve gayrimenkullerine nesiller boyu kendi ahfadından olanları tayin etmekteydiler.

\section{Sonuç}

Urfa'da vakıf kitaplarına ve kütüphanelerine baktığımızda, vakıf kurucularının büyük çoğunluğunun şeyh, âlim, hafiz ve şair olduğu görülmektedir. Vakfedilen kitapların ise döneminin eğitim ve kültür hayatıyla örtüşen kitaplar olduğunu görürüz. Vakfedilen bu kitapların, devrin OsmanI eğitim sistemiyle örtüşen ve daha çok dinî ve tasavvufî mahiyette olduğu görülmektedir.

Şeyh Ramazan Efendi 36 adet, Hacı Kurra Efendizâde Mehmet Halid ve Mehmet Salih Efendiler 126, Dede Osman Efendi 49 ve Hafiz Mustafa bin Hasan Efendi 239 adet olmak üzere toplam 450 adet kitap vakfetmişlerdir. Bu vakfiyelerden üçü tekke ve zaviyeye, biri ise daha önce zikredildiği gibi aile efradına verilmek üzere vakfedilmiştir. $\mathrm{Bu}$ vakfiyelerden anlaşılacağı üzere kitapların muhafaza edilmesi için müstakil bir kütüphane binası inşa edilmemiştir. Dolayısıyla bu kitapların daha çok mezkûr tekke ve zaviyelerdeki talebe ve dervişlerin istifadesine sunulduğu, halkın bunlardan doğrudan yararlanamadığı görülmektedir. Müstakil bir kütüphane binasının yapılıp kitapların konulmasına dair zikredilen vakfiyelerde şart bulunmamasının nedenini biraz da vakfedilen kitapların niceliğinde aramak gerekir. Zira tek başlarına değerlendirildiğinde müstakil bir kütüphane kurulmasını gerektirecek sayıda kitabın vakfedilmediği görülmektedir. 


\section{Kaynaklar}

\section{Arşiv Kaynakları}

Urfa Şer'iyye Sicilleri: UŞS, nr.211: 557; nr.219: 557; nr. 225: 599

Tapu ve Kadastro Genel Müdürlüğü Arşivi: TGMA, nr. 574, s.1-2.

Başbakanlık Osmanlı Arşivleri, BOA EV. Mkt.1352

Vakıflar Genel Müdürlüğü Arşivi: VGMA, Defter 2150/1, Defter 1090; Defter nr.1084

\section{Araştirma ve İnceleme Eserler}

El Cuburi, Abdullah (H. 1389/M. 1969), Mektebetü'I-Evkafi'I-Amme, Tarihuha ve Revadiru Mahtutatiha, Bağdat: Meccelletü'r-Risâleti'l-islamiye (Matbaatü'l Maarif),

Akgündüz, Ahmet ( 1996). İslam ve Osmanlı Tatbikatında Vakıf Müessesesi, İstanbul.

Akgündüz, Murat ( 2012). Osmanlı Medreseleri, Beyan Yay. İstanbul.

Albayrak, Sadık (1977). Son Devir Osmanlı Uleması, Medrese Yay. İstanbul.

Alpay, Bedri (1986). Urfa Şairleri, Şanlıurfa.

Anameriç, Hakan (2009). “Osmanlılarda Kütüphane Kültürü ve Bilimsel Yaşama Etkisi”, VI.

Uluslararası Türk Kültürü Kongresi Bildirileri, C.Il, yay. haz. Şebnem Ercebeci, Ankara.

Barkan, Ömer Lütfi (1963). "İmaret Sitelerinin Kuruluş ve İşleyiş Tarzına Ait Araşttrmalar", iktisat Fakültesi Mecmuası, C.XXIII, İstanbul, ss. 238-296.

Çetinkaya, Bayram Ali ( 2013). Medine'den Medeniyete, İnsan Yay. İstanbul.

Ekinci, Abdullah ( 2006). Ortaçağda Urfa, Kitabevi Yay. Ankara.

Erünsal, İsmail E. (2008). Osmanlı Vakıf Kütüphaneleri, TTK Yay. Ankara.

Erünsal, İsmail E. (1991). Türk Kütüphaneleri Tarihi-I, C.2, TTK Yay. Ankara.

Erünsal, İsmail E. (2014). Osmanlı Kültür Tarihinin Bilinmeyenleri, Timaş Yay. İstanbul.

Güler, Selahaddin Eyyubi (2012). Urfalı Nakşibendi Şeyhi Hacı Müslüm Hafiz Efendi Hazretleri, Şanlıurfa.

Hayes, E. R. (2002). Urfa Akademisi, Çev. Yaşar Günenç, Yaba Yay. İstanbul.

Kahraman Seyit Ali - Dağlı Yücel (2010). Evliya Çelebi Seyahatnâmesi, C. 3, YKY. Yay., İstanbul.

Karakaş, Mahmut (2012). Cumhuriyet Öncesi Şanlıurfa'da Kültür ve Eğitim, Şanlıurfa Valiliği Yay., Konya.

Karakaş, Mahmut (1996). Şanlıurfa Evliya ve Âlimleri, Şanlıurfa Belediyesi Yay., Şanlıurfa.

Karakaş, Mahmut (2009). Urfa’nın Kültür ve İnançlar Serüveni, Şanlıurfa Valiliği Yay., Ankara

Karakeçili, Enver (2015). Urfa'da Halilu'r-Rahman Vakıfları (XVI.-XX. Yüzyıl Başları), Y.B.Ü., Yayımlanmamış Yüksek Lisans Tezi, Ankara.

Kapaklı, Kemal (2012). "1324 tarihli Halep Vilayet Salnamesinde Urfa Sancağı'ndaki Mekteb ve Kütüphaneler”, Şanlıurfa Kültür Sanat Tarih ve Turizm Dergisi, Sayı 14, Şanlıurfa, ss. 26-29.

Kazıcı, Ziya- Şeker, Mehmet (1982). İslam Türk Medeniyeti Tarihi, (ilaveli ikinci baskı) İstanbul.

Köprülü, Fuat (1983). İslam ve Türk Hukuk Tarihi Araştırmaları ve Vakıf Müessesesi, İstanbul.

Kurtoğlu, Mehmet (2011), "Şair Sakıb Efendi Hayat, Vakfiyesi ve Vakfettiği Kitaplar”, Vakıflar Dergisi, Sayı 34, VGM. Yay., Ankara, ss. 107-154.

Kurtoğlu, Mehmet (2011). İbrahimin Nazargâhı Urfa, Bengü Yay. Ankara.

Memiş, Mehmet (1998). Şanlıurfa Medreseleri, Sosyal Bilimler Enstitüsü, Yayımlanmamış Doktora Tezi, İstanbul. 
Memiş, Mehmet (2011). "Medreseler", Şanlıurfa'da Dini Hayat (Edit. Yusuf Ziya Keskin), TDV Yay., Ankara, ss. 157-187.

Öğüt, Tahir (2013). 18-19. yy.'da Birecik Sancağında iktisadi ve Sosyal Yapı, TTK Yay., Ankara.

Öngül, Ali ( 2004). Urfa Tarihi, Emek Matbaası, Manisa.

Özdemir, Ulaş Salih (2014). Siyasal Kimliğiyle Urfa Mebusu Şeyh Safvet Efendi, Gürer Yay. İstanbul.

Özel, Ahmet (2014). Hanefi Fıkıh Alimleri ve Diğer Mezheplerin Meşhurları, TDV. Yay., Ankara.

Öztürk, Nazif (1983). Menşei ve Tarihi Gelişimi Açısından Vakıflar, VGM. Yay., Ankara.

Öztürk, Nazif (1995). Türk Yenileşme Tarihi Çerçevesinde Vakıf Müessesesi, TDV. Yay, Ankara.

Öztürk, Nazif (1995). Elmalılı M.Hamdi Yazır Gözüyle Vakıflar, TDV. Yay. Ankara.

Tenik, Ali (2011). “Tekke ve Zaviyeler”, Geçmişten Günümüze Şanlıurfa'da Dinî Hayat (Edit.Yusuf Ziya Keskin), TDV Yay., Ankara 2011, ss. 195-210.

Turan, Ahmet Nezihi ( 2012), XVI. Yüzyılda Ruha(Urfa) Sancağı, TTK. Yay., Ankara.

Segal, Judah B. ( 2002). Edessa (Urfa) Kutsal Şehir, Çev. Ahmet Arslan, İletişim Yay. İstanbul.

Schmidt, Klaus (2007). Göbekli Tepe En Eski Tapınağı Yapanlar, Çev. Rüstem Arslan, Arkeoloji ve Sanat Yay., İstanbul.

Şeşen, Ramazan (1993). Harran Tarihi, TDV Yay. İstanbul.

Yediyıldız, Bahaeddin ( 2003). XVIII. Yüzyılda Türkiye'de Vakıf Müessesesi, TTK.Yay., Ankara.

Yediyıldız, Bahaeddin (1989). “islamıda Vakıf, Doğuştan” Günümüze Büyük İslam Tarihi, C.14 (4) , İstanbul.

Yıldız, Nuray (2003). Kalıntılar ve Edebi Kaynaklara Işığında Antik Çağ Kütüphaneleri, Arkeoloji ve Sanat Yay., İstanbul. 


\section{Ekler}

Ek 1. Hafiz Mustafa bin Hasan'a Ait 25 Ramazan 1312/ 22 Mart 1895 Tarihli Vakfiye ve 24 Zilhicce 1320/24 Mart 1903 Tarihli Zeyl Vakfiye.(UŞS, nr.219: 557)

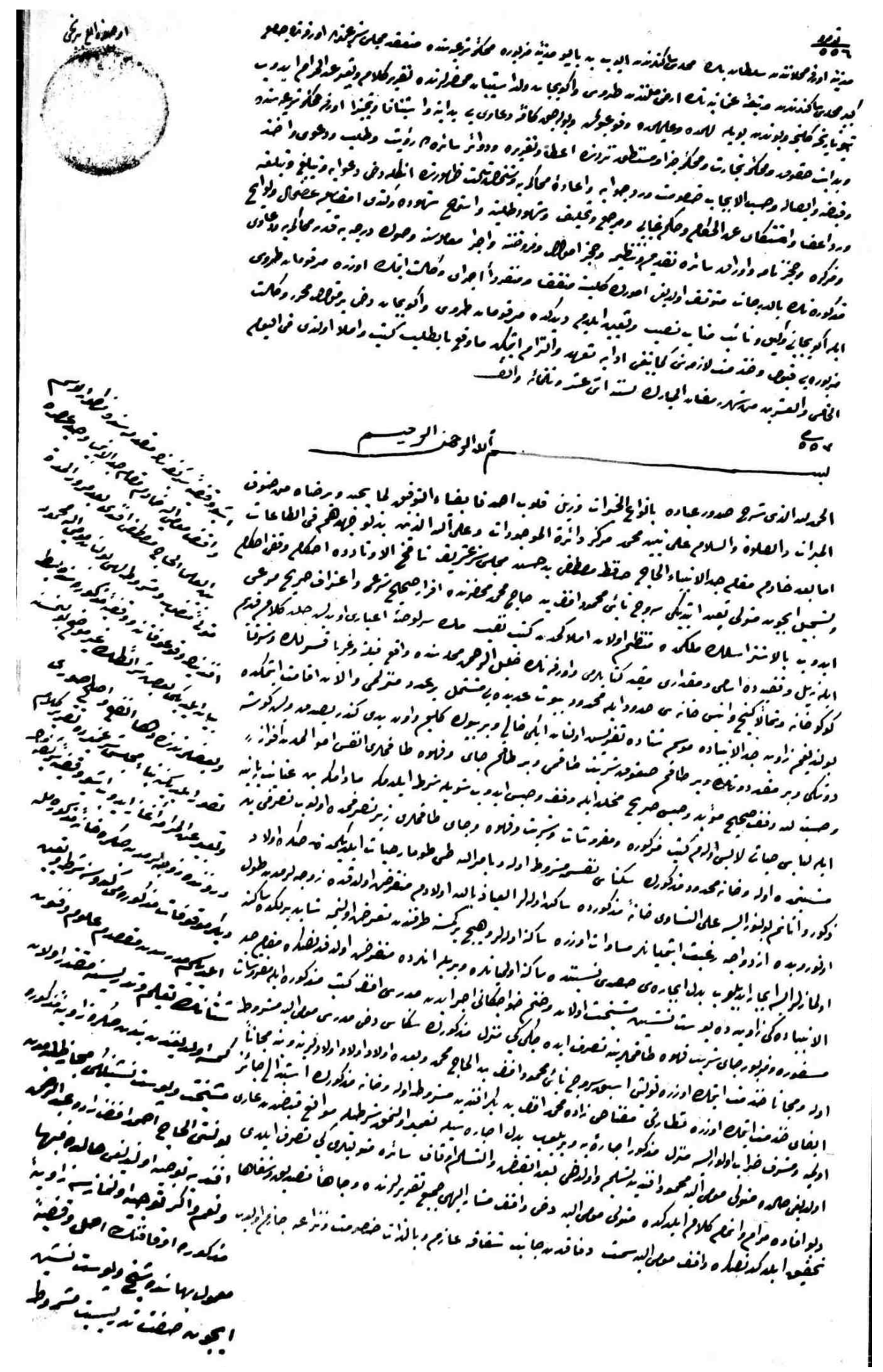




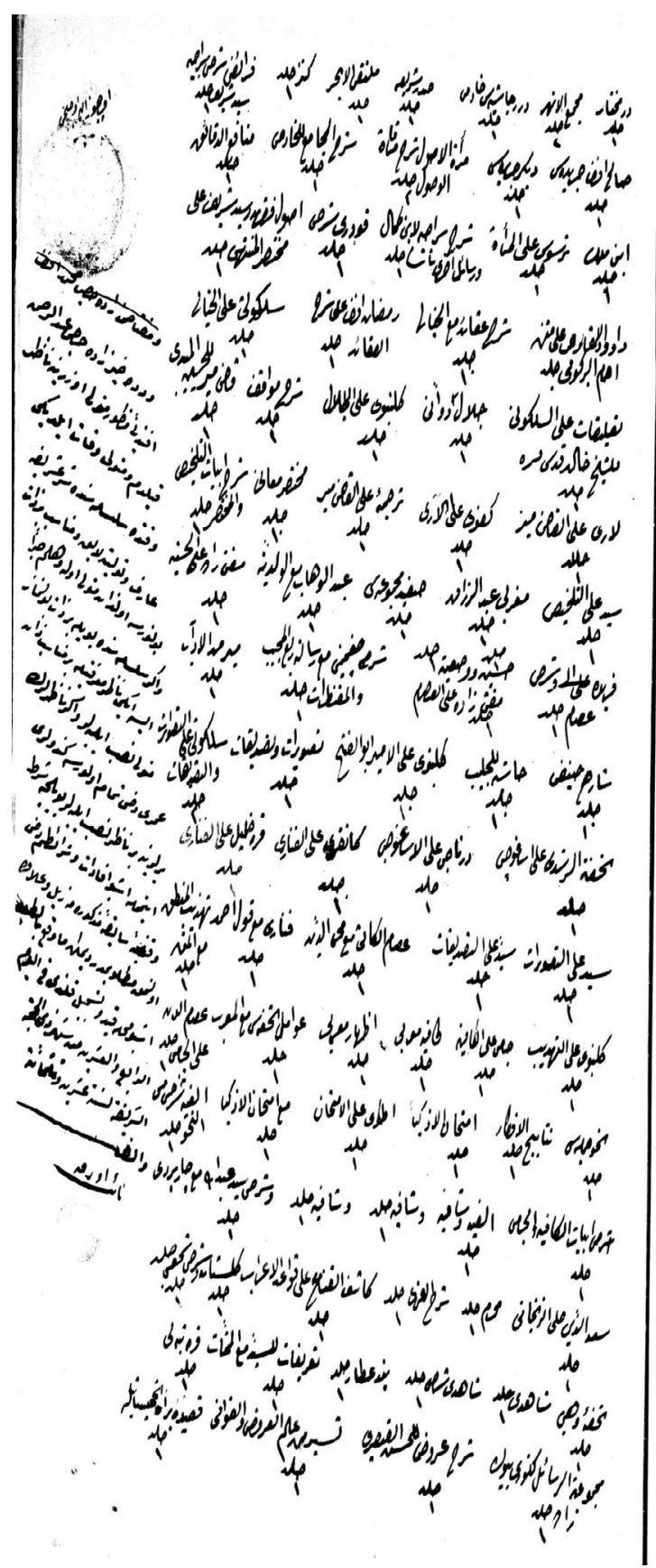

كذبر

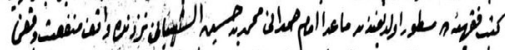

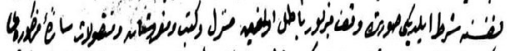

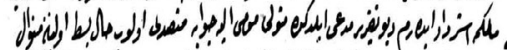

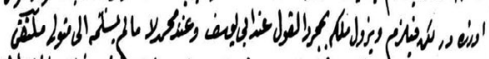

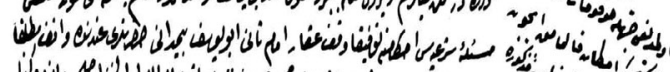
ه.

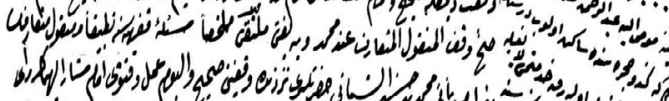

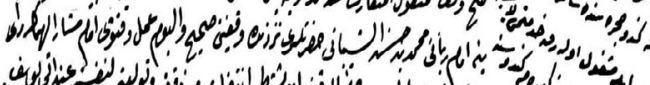

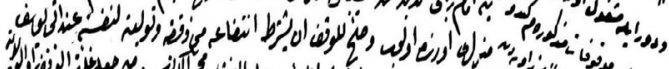

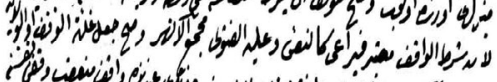

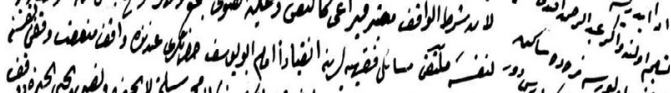

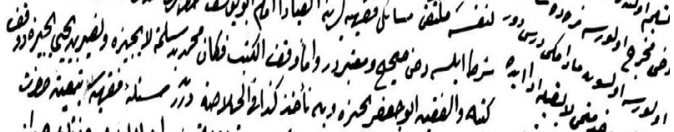

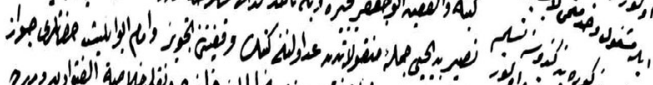

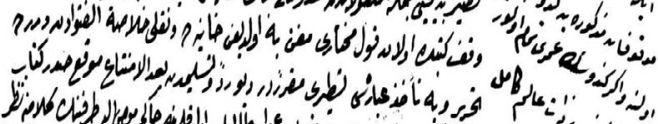

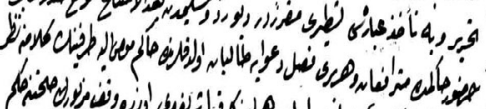

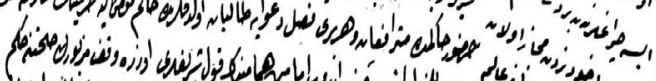

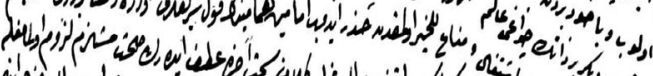

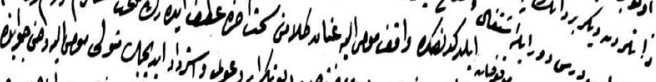

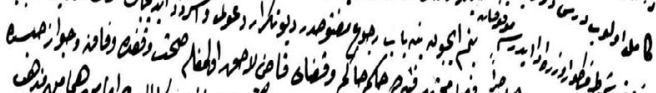

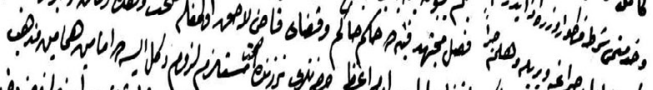

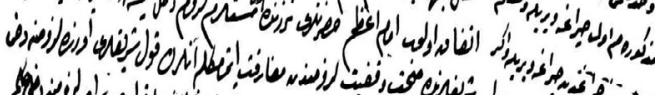

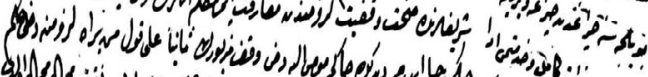
罗

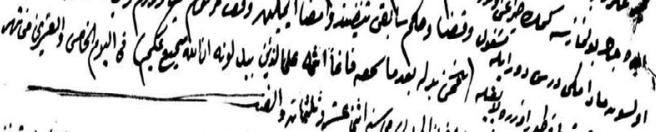

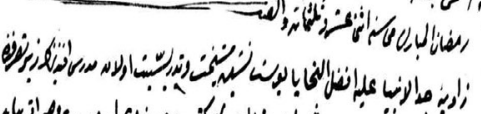

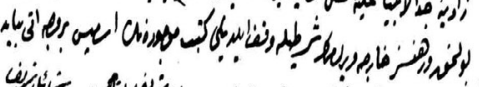

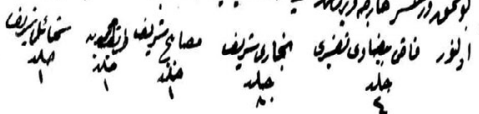

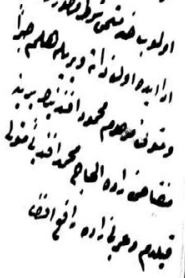


Hâfiz Mustafa bin Hasan'ın 25 Ramazan 1312/ 22 Mart 1895 Tarihli Vakfiye'sinde Ayn-ı Halilu'r-Rahman Vakfi'na Vakfettiği Kitapların Listesi (UŞS, nr.219: 557).

Zâviye-i ceddü'l-enbiyâ aleyh efdalü't-tahaya post-nişîn-i meşîhat ve tederrüsiyet olan müderris efendinin zir-i tasarrufunda bulunmak ve rehinsiz hârice verilmemek şartyla vakf eylediği kitâb-ı mevcudenin esâmîsi ber-vechi ati beyân olunur.

\begin{tabular}{|c|c|}
\hline Kitap Adı & Adeti \\
\hline Kâdı-i Beydavî Tefsîri & 4 cilt \\
\hline Buhârî-i Şerîf & 8 cilt \\
\hline Mesâbîh-i Şerîf & 1 cilt \\
\hline Tarîkat-ı Muhammediye & 1 cilt \\
\hline Şemâil-i Şerîf & 1 cilt \\
\hline Dürrü Muhtâr & 1 cilt \\
\hline Mecma'u'l-Enhur & 2 cilt \\
\hline Dürer Hâşiyesi Hadimî & 1 cilt \\
\hline Sadr-ı Şeri'a & 1 cilt \\
\hline Mülteka'I-Ebhur & 1 cilt \\
\hline Kenz & 1 cilt \\
\hline Ferâiz Şerhi Sirâciye (Seyid Şerîf ) & 1 cilt \\
\hline Salih Efendi Cerîdesi & 1 cilt \\
\hline Diğer Cerîdesi & 1 cilt \\
\hline Mir'âtül'I-Usûl Şerhu Mik'atu'I-Vüsûl & 2 cilt \\
\hline Şerhu'I-Câmi' li'I-Hadimî & 1 cilt \\
\hline Menâfi'u'd-Dekâik & 1 cilt \\
\hline İbn-i Melek & 1 cilt \\
\hline Tarsus ale'I-Mir'ât & 1 cilt \\
\hline Şerhu Sirâciye li-ibn Kemal Paşa ve Resâil-i Uhrâ & $1 \mathrm{cilt}$ \\
\hline Kudûrî Şerhi & 1 cilt \\
\hline Usûl-ı Fıkıh ve Seyid Şerîf alâ Muhtasarı'I-Münteha & 1 cilt \\
\hline Dâvudu'l-Karsî alâ metni İmâm el-Birgivî & 0 cilt \\
\hline Şerhu Akâid ma'a'l-Hayâlî & 1 cilt \\
\hline Ramazan Efendi alâ Şerhi'l-Akâid & 1 cilt \\
\hline Selekuti ale'l-Hayâlî & 1 cilt \\
\hline Talikat ale's-Selekuti li-Şeyh Halid Kuddise Sirruhu & 1 cilt \\
\hline Celâl Devvânî & 1 cilt \\
\hline Gelenbevî ale'I- Celâl & 1 cilt \\
\hline Şerhi Mevâkıf & 1 cilt \\
\hline Kadî Mîr li'l- Hüseyin el-Mübeydi & 1 cilt \\
\hline Lari ale'l Kadı Mîr & $1 \mathrm{cilt}$ \\
\hline
\end{tabular}




\begin{tabular}{|c|c|}
\hline Kitap Adı & Adeti \\
\hline Kefevî ale'l- Lârî & 1 cilt \\
\hline Tercüme ale'l- Kadî Mîr & 1 cilt \\
\hline Muhtasar-i Ma'ânî & 1 cilt \\
\hline Şerhu Ebyatu't-Telhîs ve'l- Muhtasar & 1 cilt \\
\hline Seyid ale't-Telhîs & 1 cilt \\
\hline Mağribî Abdurrezzak & 1 cilt \\
\hline Hafîd Mecmûası & 1 cilt \\
\hline Abdulvahab ma'a'l-Velediye & 1 cilt \\
\hline Müftizâde ale'l- Hüseyniye & 1 cilt \\
\hline Feride ve Şerhi İsâm & 1 cilt \\
\hline Abdulvahab ma'a'I-Velediye & 1 cilt \\
\hline Müftizâde ale'l- Hüseyniye & 1 cilt \\
\hline Feride ve Şerhi İsâm & 1 cilt \\
\hline Şerhu Çağminî ma'a Risâle-i Rub'u'I- Mucib ve'I-Mukantarat & 1 cilt \\
\hline Mîr Mine'l- Âdâb & 1 cilt \\
\hline Şârih-i Hanifî & 1 cilt \\
\hline Hâşiye li'l-Celib & 1 cilt \\
\hline Gelenbevî ale'I-Emîr Ebu'I-Feth & 1 cilt \\
\hline Tasvîrât ve Tasdîkât & $1 \mathrm{cilt}$ \\
\hline Selkutî ale't- Tasvîrât ve't-Tasdîkât & 1 cilt \\
\hline Tuhfetu'r-Rüşdi alâ- İsegocî & 1 cilt \\
\hline Dürrü Nâcî ale'|- İsegocî & 1 cilt \\
\hline Kangırî ale'I-Fenarî & 1 cilt \\
\hline Kara Halil ale'I-Fenarî & $1 \mathrm{cilt}$ \\
\hline Seyid ale't-Tasavvurât & 1 cilt \\
\hline Seyidale't-Tasdîkât & 1 cilt \\
\hline İsâm el-Kati ma'a Muhyiddin & 1 cilt \\
\hline Fenarî ma‘a Kul Ahmed & $1 \mathrm{cilt}$ \\
\hline Tehzibu'I-Mantkk ma'a'I-Metin & 1 cilt \\
\hline Gelenbevî ale't-Tehzib & 1 cilt \\
\hline Câmî ale'I-Kâfiye & 1 cilt \\
\hline Kâfiye Mu'ribî & $1 \mathrm{cilt}$ \\
\hline İzhar Mu'ribî & 1 cilt \\
\hline Avâmil Tuhfesi ma'a'I-Mu'rib & 1 cilt \\
\hline İsâmuddin ale'I-Câmî & 1 cilt \\
\hline Nahiv Cümlesi & 1 cilt \\
\hline Netâyicu'l-Efkâr & 1 cilt \\
\hline
\end{tabular}




\begin{tabular}{|c|c|}
\hline Kitap Adı & Adeti \\
\hline İmtihânu'l-Ezkiyâ & 1 cilt \\
\hline Adavî ale'l-İmtihân & 1 cilt \\
\hline Ma'a İmtihânu'l-Ezkiyâ & 1 cilt \\
\hline Elfiye Şerhi mine'n-Nahvî & 1 cilt \\
\hline Ş̧erhi Ebyatu'I-Kâfiye ve'I-Câmi' & 1 cilt \\
\hline Elfiye ve Şâfiye & 1 cilt \\
\hline Şâfiye ve Şâfiye & 1 cilt \\
\hline Şerhi Seyid Abdullah ma‘a Çarperdi & 1 cilt \\
\hline Sadeddinale'z-Zencanî & 1 cilt \\
\hline Muharrem & 1 cilt \\
\hline Şerhi İzzi & 1 cilt \\
\hline Kaşifu'I-Kına' alâ Kavbaidi'I-I'rab & 1 cilt \\
\hline Gülistân & 1 cilt \\
\hline Şerhi Şem'i & 1 cilt \\
\hline Tuhfe-i Vehbi & 1 cilt \\
\hline Şâhidî & 1 cilt \\
\hline Şâhidî Şerhi & 1 cilt \\
\hline Pend-i Attar & 1 cilt \\
\hline Ta'rîfât li-Seyid ma'a'l- ... & 1 cilt \\
\hline Karatepeli & 1 cilt \\
\hline Mecmûatu'r-Resâil-i Kutûrî-i Büyük & 1 cilt \\
\hline Şerhi Aruz li'I-Muhsini'I-Kayserî & 1 cilt \\
\hline Teysir min ilmi'l-Aruz ve'I-Kavafí & 1 cilt \\
\hline Kasîde-i Bürde & 1 cilt \\
\hline Şerhi Bürde & 1 cilt \\
\hline Usûl-ı Hadîsten Nuhbe Şerhi & 1 cilt \\
\hline Telhizli'I-Hatîbi'd-Dımışkî & 1 cilt \\
\hline Mecmûatu'l-Resâil fi-Hakkı Zikir & 1 cilt \\
\hline Kitâbu'I-Kerahiye & 1 cilt \\
\hline Ta'lîmu'I-Müteallim & 1 cilt \\
\hline Mecmûatu'l-Ezkar ve'd-Davât & 1 cilt \\
\hline İstidlaliye & 1 cilt \\
\hline Akyise alâ't-Tasavvurât ve't-Tasdîkât & 1 cilt \\
\hline Mecmûatu'l- Kavâid & 1 cilt \\
\hline Şemsiye & 1 cilt \\
\hline Musevîye ve Hâşiyesi & Birer cilt \\
\hline Subha-i Subyân & 1 cilt \\
\hline
\end{tabular}




\begin{tabular}{|c|c|}
\hline Kitap Adı & Adeti \\
\hline Manzûme-i İsmail Hakkı fi'I- Kaide fî- Lisân-ı Türkî & 1 cilt \\
\hline Hasan Zibarî ale’l-İsâm & 1 cilt \\
\hline Kasîde-i Bürde ve Nuniye ve Emavî ve Tantaraniye & 1 cilt \\
\hline Hikmet-i İslâmiye li- İbrahim el-Karamanî el Amidî & 1 cilt \\
\hline Vaziye Şerhi & 1 cilt \\
\hline Kasîde-i Münferice Şerhi & 1 cilt \\
\hline Muhtasaru'I-VelayeTercemesi & 1 cilt \\
\hline Talikat ale's-Seyid & 1 cilt \\
\hline Hâşiye-i Muhtasar el-Müntehî & 1 cilt \\
\hline Merah & 1 cilt \\
\hline Mecâlis-i Konevî & 1 cilt \\
\hline Halebî ve Şerhi Hilyetu’n-Nâcî & 1 cilt \\
\hline Delâil-i Şerîf & 1 cilt \\
\hline Aliyu'l-Kârî ale'ş-Şifâ & 1 cilt \\
\hline Berika Şerhi Tarîka-i Muhammediye & 1 cilt \\
\hline Dürer & 1 cilt \\
\hline Fetvâ-i Ali Efendi & 1 cilt \\
\hline Fevâid-i Feyyaziyeli'I-Câmi & 1 cilt \\
\hline Kâmûs Tercemesi Okyanus & 1 cilt \\
\hline Muhammediye & 1 cilt \\
\hline Kara Davud & 1 cilt \\
\hline Dürretü'n-Nâsihîn & 1 cilt \\
\hline Mülteka'l- Ebhur & 1 cilt \\
\hline Buhârî-i Şerîf & 4 cilt \\
\hline Hâşiye-i Ebi'n-Neca alâ Şerhi Şeyh Halid & 1 cilt \\
\hline Hâşiye-i Şeyh Hasan el-Attar alâ Şerhi'l- Ezheriye & $1 \mathrm{cilt}$ \\
\hline Şerhu Fevaki el-Ceniye alâ Medni'l- Ecrubiye & 1 cilt \\
\hline Meraku'I- Felah & 1 cilt \\
\hline Vecihi Paşazâde Kemal Paşa'nın Mecmûa-i Manzûmesi & 1 cilt \\
\hline Ahmedîye & 1 cilt \\
\hline Mustafa Mevlidi & 1 cilt \\
\hline Mevlid-i İzzet & 1 cilt \\
\hline Dürrü Yekta & 1 cilt \\
\hline Mürşidü'l Müteehhilin & 1 cilt \\
\hline Tuhfe-i Vehbi & 1 cilt \\
\hline Hatîm Duâsı & 1 cilt \\
\hline Ramazan Methi & 1 cilt \\
\hline
\end{tabular}




\begin{tabular}{|c|c|}
\hline Kitap Adı & Adeti \\
\hline Dürretü’n-Nâsihîn & -- \\
\hline Mevize-i Hasena & -- \\
\hline Îmanu'I-Enzar ma'a Ruhu'ş-Şuruh & -- \\
\hline Menâsiku'I-Hac & 1 adet \\
\hline Seyid ale't-Tasavvvurat ve't-Tasdîkât & 1 adet \\
\hline Kedusî ale'l-İrtifâ & 1 adet \\
\hline Şerhu Aliyu'I-Kârî ale'I-Emari & 1 adet \\
\hline Câmi'-i Sağîr & 1 adet \\
\hline Kasîde Şerhi Harbutî & 1 adet \\
\hline Cerîdetu'I-Ferâiz Hamza Efendi & 1 adet \\
\hline Seyid Şerîf ale's-Siraciye & 1 adet \\
\hline Molla Câmi' & 1 adet \\
\hline Mülteka & 1 adet \\
\hline Delâil'I-Hayrât & 2 adet \\
\hline Mesnevî-i Şerîf & 1 adet \\
\hline Haleb-i Sağîr & 2 Adet \\
\hline Tuhfetu'I-Ihvan ale'I-Evamil & 1 adet \\
\hline Mesâbîh-i Şerîf & 1 adet \\
\hline Muhtasar-ı Maani & 1 adet \\
\hline Kâfiye Mu'ribi & 1 adet \\
\hline Fevâid Mecmûası & 1 adet \\
\hline Muhammediye & 1 adet \\
\hline Kasîde-i Bürde & 1 adet \\
\hline İzhar Mu'ribi & 1 adet \\
\hline Tasdîkât Mantık Cümlesi & 3 adet \\
\hline Mefhum-ו Maksud & 1 adet \\
\hline Muharrem ale'I-Câmî & 2 adet \\
\hline Dürer-i Şerhi Gurer & 2 adet \\
\hline Sarf Cümlesi & 1 adet \\
\hline Gülistân-ı Sa'di & 1 adet \\
\hline Mülteka'I Ebhur & 1 adet \\
\hline Kasîde-i Bürde Şerhi Harputî & 1 adet \\
\hline Mecmûa-i Hutbe & 1 adet \\
\hline Manzum Şerh-i Manzum & 1 adet \\
\hline En-Muzec? & 1 adet \\
\hline Şerhi Niyazi ale'I Birgivî & 1 adet \\
\hline Taşköprü & 1 adet \\
\hline
\end{tabular}




\begin{tabular}{|c|c|}
\hline Kitap Adı & Adeti \\
\hline Kasîde Şerhi aliyu'I-Kârî & 1 adet \\
\hline Hal-i Rumuz Kasîde-i İsmet & 1 adet \\
\hline Buhâri & 1 adet \\
\hline Velediye & 1 adet \\
\hline Nusretu'l-Cunûd & 1 adet \\
\hline Kavâid-i Farîsîye & 1 adet \\
\hline Lüccetu'I- Esrâr li-Mevlânâ Câmî & 1 adet \\
\hline Mecmûa-i i'lal & 1 adet \\
\hline Şâfiye & - \\
\hline Celâlü'd-Devvanî & 1 adet \\
\hline Nahiv Cümlesi & 1 adet \\
\hline Esami-i Ashb-ı Bedir & 1 adet \\
\hline Hizbu Bahir & 1 adet \\
\hline Husam Kât & 1 adet \\
\hline Menâsiku'I-Hac & 1 adet \\
\hline Cevhere-i Şerh Vasiyet-i İmâm-ı Azâm & 1 adet \\
\hline Yâsin-i Şerîf Cümlesi & 1 adet \\
\hline Cezerî & 1 adet \\
\hline Feride? & 1 adet \\
\hline Tercüme-i Suyûfu'l- Akvati' & - \\
\hline Dîvân-ı Şemsu'I- Hakâyık & - \\
\hline Mevlevî & 1 adet \\
\hline Yazma Tıb Farîsî İshak Efendi Kasîdesi & 1 adet \\
\hline Mîr Ebu'l- Feth & 1 adet \\
\hline Câmi' & 1 adet \\
\hline Mecmûa-i Gazeliyyât & 1 adet \\
\hline Tasavvurât ve Tasdîkât & - \\
\hline Vankulu Cild-i Evveli & 1 adet \\
\hline Mehmed Emin ale'l Fenarî & - \\
\hline Şifâ-yı Şerîf & 1 adet \\
\hline Dürretu'I-Vaizin & - \\
\hline Elfiye Şerhi & 1 adet \\
\hline Şerhu Akâid ma'a'l-Hayâlî & 1 adet \\
\hline Dâmâd & 1 adet \\
\hline Muharrem ale'I-Câmi' & 1 adet \\
\hline Tehzibu'I-Mantik & - \\
\hline
\end{tabular}


Ek 2. Ramazan Efendi'nin Tekye-i Cedide'ye Konulmak Üzere Vakfettiği Kitaplara İlişkin h.1072/1661 Tarihli Kayıt (TKGMA, nr.574, s. 1-2.)

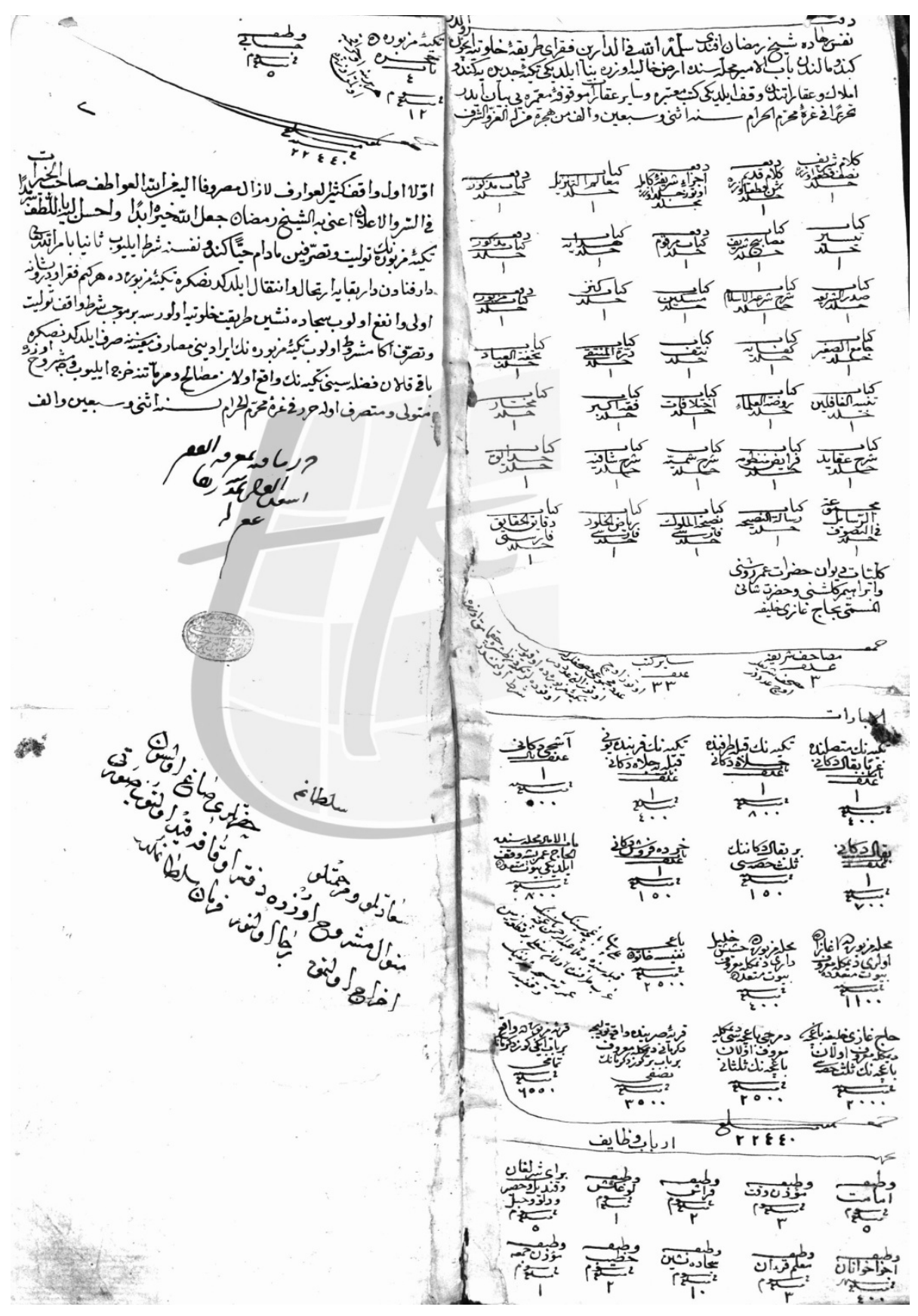

Ramazan Efendi'nin Tekye-i Cedide'ye Konulmak Üzere Vakfettiği Kitaplara Illişkin h.1072/1661 Tarihli Belgenin Transkripsiyonu (TKGMA, nr. 574, s. 1-2)

Nefs-i Ruha'da Şeyh Ramazan Efendi sellemehullahu fi'd-dareyn fukarâ-yı tarîka-i Halvetiye içun kendu malından Babu'I-Emir Mahallesi'nde arz-ı halîye üzere binâ eylediği Tekye-i Cedîde'ye kendu emlâk ve akarâtından vakfeylediği kütüb-i mu'tebere vesair akarât-ı mevkûfe-i muammereyi beyân eder. Tahriren fî gurre-i Muharremu'l-haram sene isney ve seb'in ve elf.(1072) Min hicreti men lehul izzu ve'ş-şeref. 


\begin{tabular}{|c|c|}
\hline Kitap Adı & Adeti \\
\hline Kelâm-ı Şerîf Nısıf Kıt'a Üzere & 1 cilt \\
\hline Def’a Kelâm-ı Kadim Sümün Kıta Üzere & $1 \mathrm{cilt}$ \\
\hline Def’a Eczâ-i Şerîfe-i Kamile Otuz cilt üzere mücelled & - \\
\hline Kitâbu Maalimu't-Tenzîl & 1 cilt \\
\hline Def'a Kitâb-ı Mezkûr & 1 cilt \\
\hline Kitâb-ı Teysir & 1 cilt \\
\hline Kitâb-ı Mesâbîh-i Şerîf & 1 cilt \\
\hline Def'a Kitâb-ı Merkûm & $1 \mathrm{cilt}$ \\
\hline Kitâb-ı Hidaye & 1 cilt \\
\hline Def'a Kitâb-ı Mezkûr & $1 \mathrm{cilt}$ \\
\hline Kitâbu Sadru'ş-Şeria & 1 cilt \\
\hline Kitâbu Şerhu Şir'atu'l-i̇slâm & 1 cilt \\
\hline Kitâbu Miskin & 1 cilt \\
\hline Kitâbu Kenz & 1 cilt \\
\hline Def'a Kitâb-ı Mezbûr & 1 cilt \\
\hline Kitâbu Câmiu's-Sağîr & 1 cilt \\
\hline Kitâbu Kâfiye (Kifaye) & 1 cilt \\
\hline Kitâbu Netif & 1 cilt \\
\hline Kitâbu Dürretü'I-Münteki & 1 cilt \\
\hline KitâbuTuhfetu'l-ibâd & $1 \mathrm{cilt}$ \\
\hline Kitâbu Tenbihu'I-Gâfilin & 1 cilt \\
\hline Kitâbu Ravzatu'I-Ulemâ & $1 \mathrm{cilt}$ \\
\hline Kitâbu İhtilafat & 1 cilt \\
\hline Kitâbu Fıkh-ו Ekber & $1 \mathrm{cilt}$ \\
\hline Kitâbu Muhtâr & $1 \mathrm{cilt}$ \\
\hline Kitâbu Şerhi Akâid & 1 cilt \\
\hline Kitâbu Faraiz-i Manzûme & 1 cilt \\
\hline Kitâbu Şerhi Şemsiye & 1 cilt \\
\hline Kitâbu Şerhu Şâfiye & 1 cilt \\
\hline Kitâbu Hadâik & 1 cilt \\
\hline Mecmûatu'r-Resâil fi't-Tasavvuf & 1 cilt \\
\hline Kitâbu Risalâtu'n-Nâsiha & 1 cilt \\
\hline Kitâbu Nâsihatu'I-Mülûk Fârisî & $1 \mathrm{cilt}$ \\
\hline Kitâbu Riyazi'I-Hulûd Fârisî & 1 Cilt \\
\hline Kitâbu Dekâiku'I-Hakâik Fârisî & 1 Cilt \\
\hline $\begin{array}{l}\text { Külliyât-ı Dîvân-ı Hazreti Ömer Ruşenî ve İbrahim Gülşeni ve Hazreti Şani el-Müsem- } \\
\text { ma bi-Hacı Gazi Halife }\end{array}$ & - \\
\hline
\end{tabular}

Külliyât-ı Divân-ı Hazret-i Ömer Ruşenî ve İbrahim Gülşenî ve Hazret-i Şânî el-Müsemma bi-Hacı Gazi Halife. Cem'ân masahif-i şerîfe adet 3. Mushaf-ı şerîfler üç adeddir. Sâir kütüb 33 aded.

Otuz üç aded mecmû'u mushaflarla otuz alt adeddir. Tekye-i mezbûrede okuyup okutalar. Tekyeden taşra çıkmamak üzere şart olunmuştur. 
Ek 3. Dede Osman Efendi'nin Mevlûd-i Halilu'r-Rahman Zaviyesine Vakfettiği Kitaplara illişkin Belge (UŞS, nr. 225: 599)

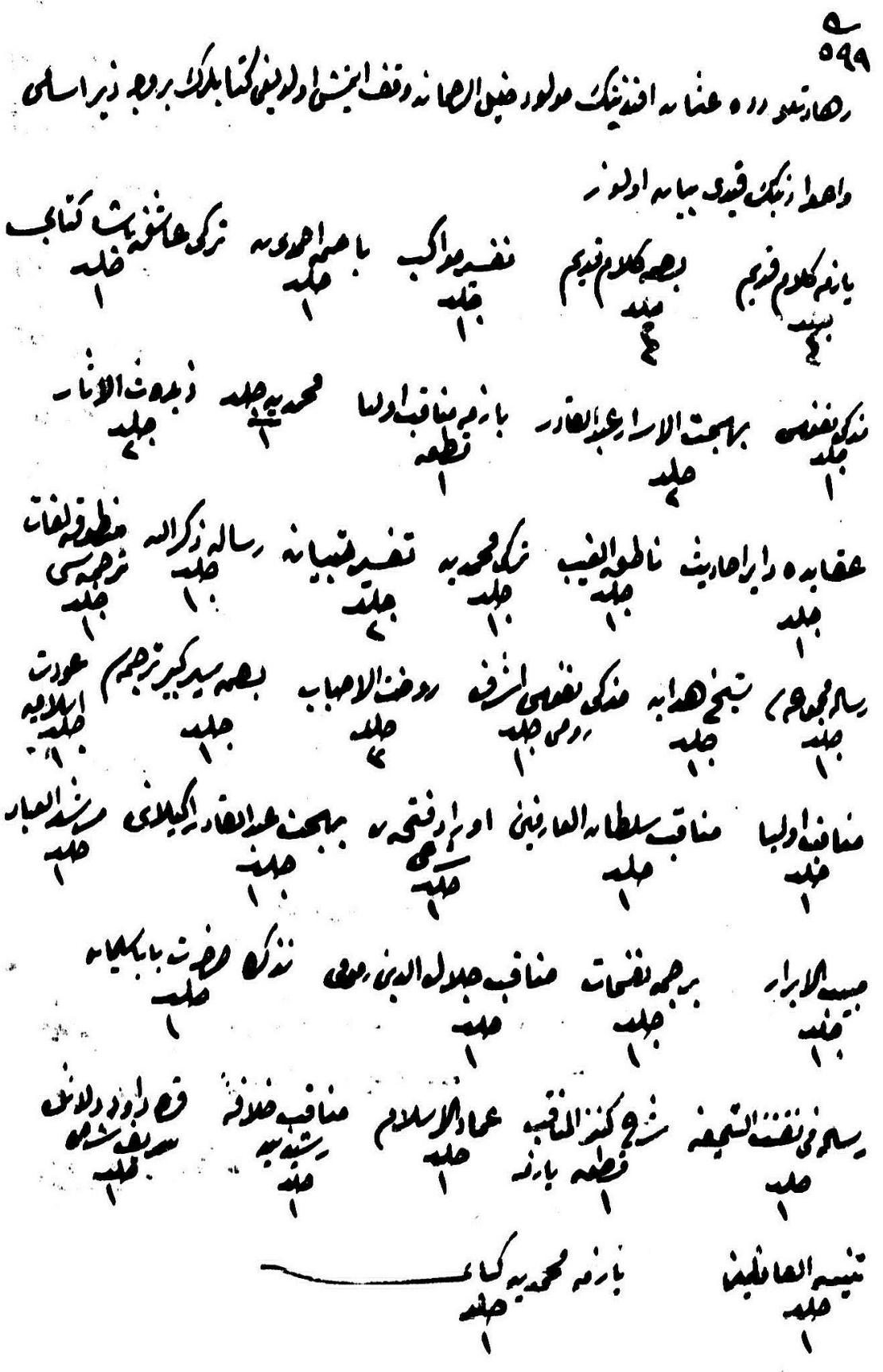

Dede Osman Efendi'nin Mevlûd-i Halilu'r-Rahman Zaviyesine Vakfettiği Kitapların Listesi (UŞS, nr. 225: 599)

Zehadetlu Dede Osman Efendi'nin Mevlûd-i Halilu'r-Rahman'a vakfetmiş olduğu kitâbların ber-vechi zîr-i esâmî ve a'dâdının kaydı beyân olunur. 


\begin{tabular}{|c|c|}
\hline Kitap Adı & Adet/Cilt \\
\hline Yazma Kelâm-ı Kadim & 4 adet \\
\hline Basma Kelâm-ı Kadim & 4 adet \\
\hline Tefsîr-i Mevâkib & 1 cilt \\
\hline Basma Ahmedîye & 1 cilt \\
\hline Türkî Âşık Paşa Kitâbı & 1 cilt \\
\hline Müzekkin-i Nüfûs & 1 cilt \\
\hline Behcetu'l-Esrâr-ı Abdulkadir & 2 cilt \\
\hline Yazma Menâkıb-i Evliyâ & 1 kıt’a \\
\hline Muhammediye & 1 cilt \\
\hline Zubdetu'I-Asâr & 2 cilt \\
\hline Akâide Dair Ehâdîs & 1 cilt \\
\hline Nâtıku'l-Gayb & 1 cilt \\
\hline Türkî Muhammediye & 1 cilt \\
\hline Tefsîr-i Tibyân & 2 cilt \\
\hline Risâle-i Zikrullah & 1 cilt \\
\hline Mantuk-i Lugât Tercemesi & 1 cilt \\
\hline Risâle Mecmûası & 1 cilt \\
\hline Şeyh Hidaye & 1 cilt \\
\hline Müzekkîn-i Nüfûs Eşref-i Rumî & 1 cilt \\
\hline Ravzatu'I-Ahbab & 3 cilt \\
\hline Basma Siyer-i Kebîr Tercümesi & 1 cilt \\
\hline Avdet-i İslâmiye & 1 cilt \\
\hline Menâkıb-ı Evliyâ & 1 cilt \\
\hline Menâkıb-ı Sultanu'I-Arifin & 1 cilt \\
\hline Evrâd-ı Fethiye Şerhi & 1 cilt \\
\hline Becet-i Abdulkadir Geylani & 1 cilt \\
\hline Mürşidi'l- Ibâd & 1 cilt \\
\hline Ceybu'l-Ebrâr? & 1 cilt \\
\hline Tercüme-i Nefahât & 1 cilt \\
\hline Menâkıb-ı Celâleddin Rumî & 1 cilt \\
\hline Tezkire-i Hazret-i Baba Süleyman & 1 cilt \\
\hline Risâle fi-... & 1 cilt \\
\hline Şerhu Kenzu'I-Menâkıb & 1 cilt \\
\hline İmâdu'I-İslâm & 1 cilt \\
\hline Menâkıb-i Hilafe-i Reşidiye & 1 cilt \\
\hline Kara Davud Delâil-i Şerîf Şerhi & 1 cilt \\
\hline Tenbihu'I-Gâfilin & 1 cilt \\
\hline Yazma Muhammediye Kitâbı & 1 cilt \\
\hline
\end{tabular}


Ek 4. Hacı Kurra Efendizâde Mehmed Halid ve Mehmed Salih Efendiler ebna-i el-Hâc Mustafa Efendi ibn-i Halil Efendi'nin h.1293/1876 Tarihli Vakfiyesi (UŞS, nr. 211: 1190).

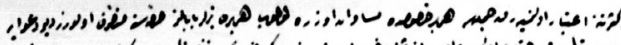

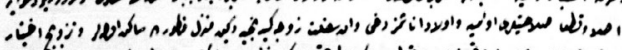

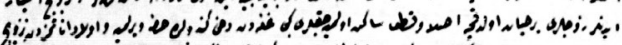

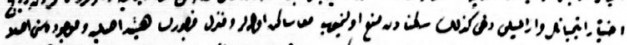

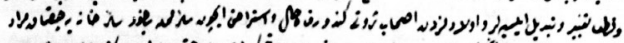

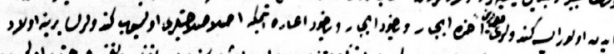

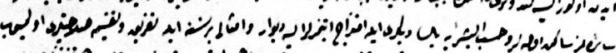

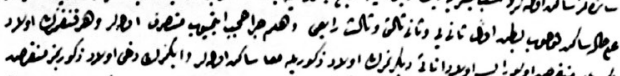

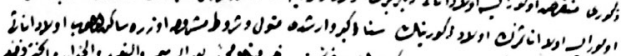

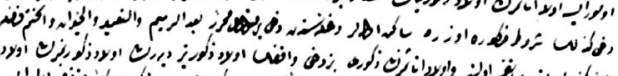

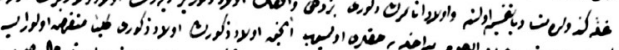

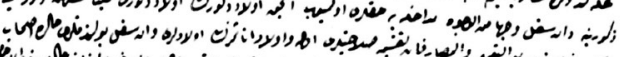

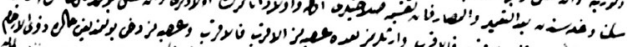

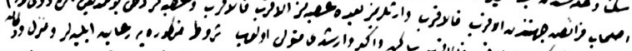

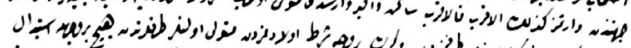

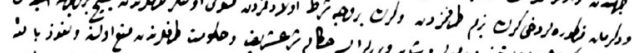

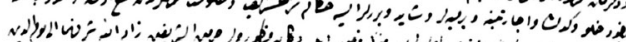

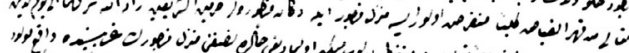

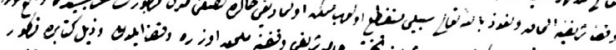

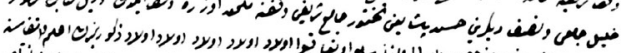

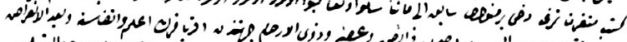

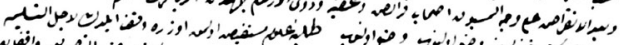

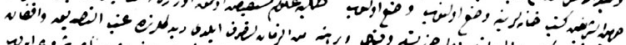

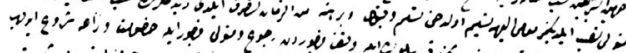

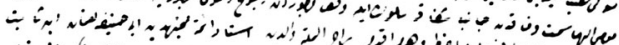

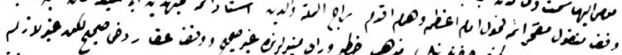

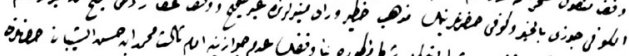

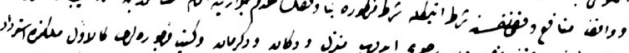

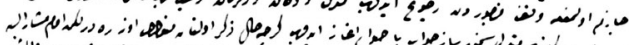

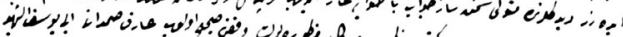

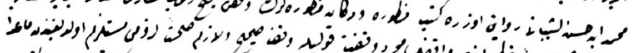

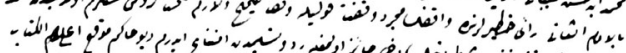

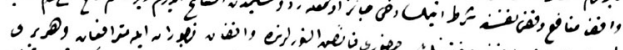

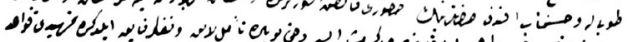

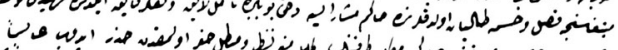

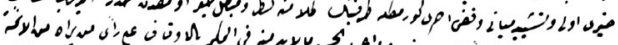

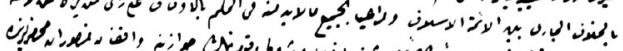

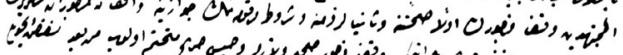

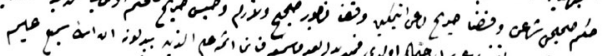

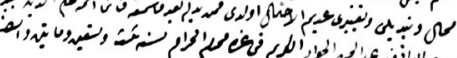

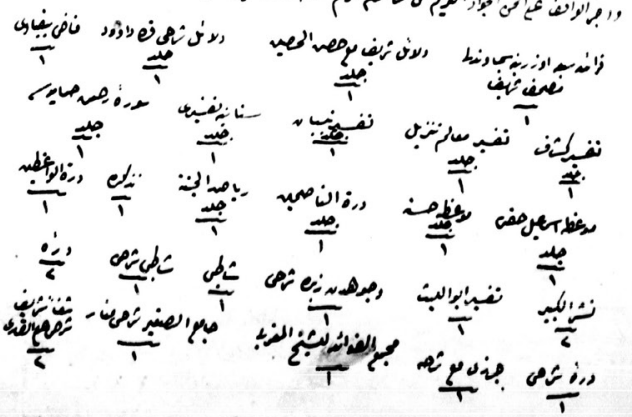

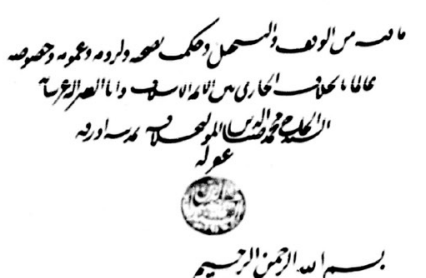

$\operatorname{lnm}$

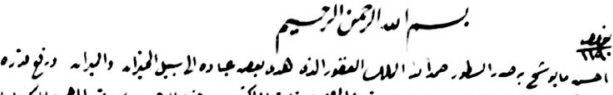

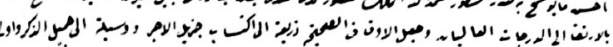

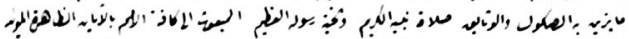

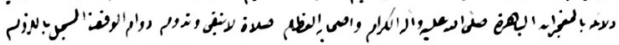

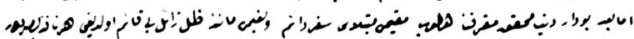

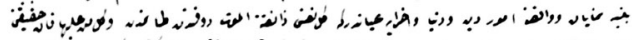

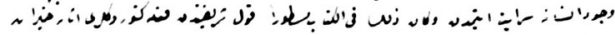

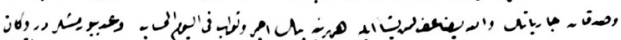

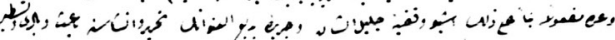

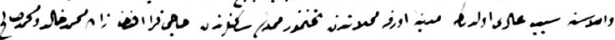

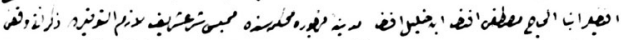

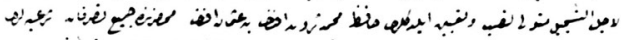

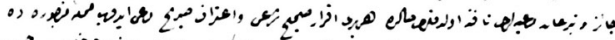

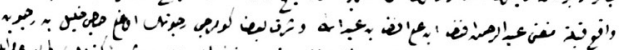

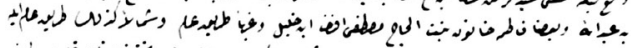

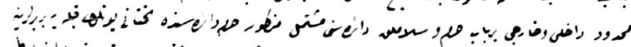

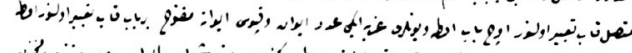

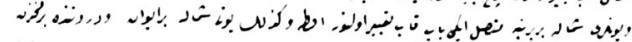

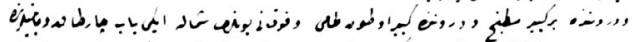

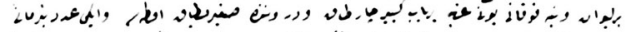

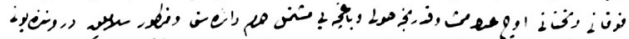

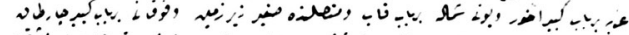

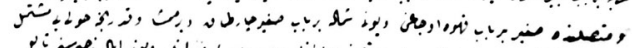

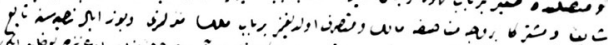

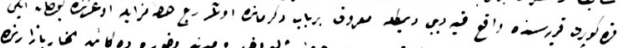

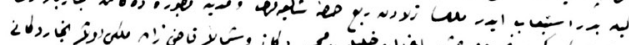

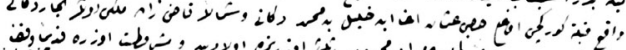

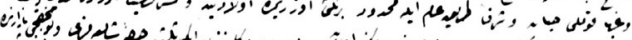

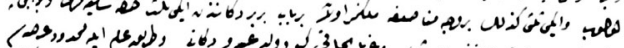

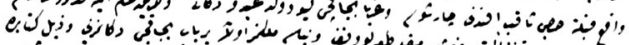

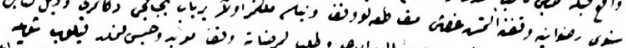

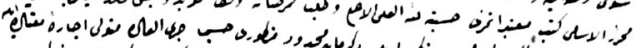

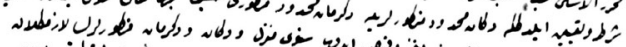

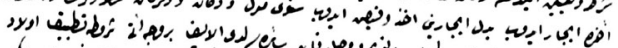

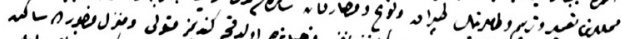

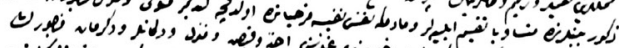

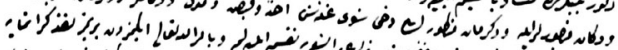

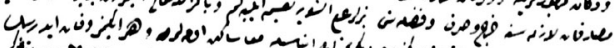

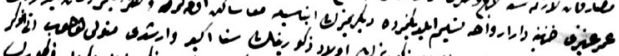

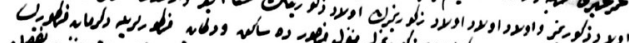

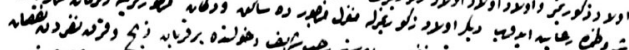

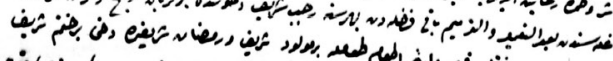

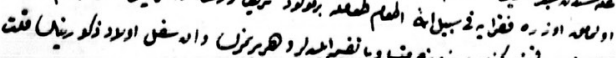




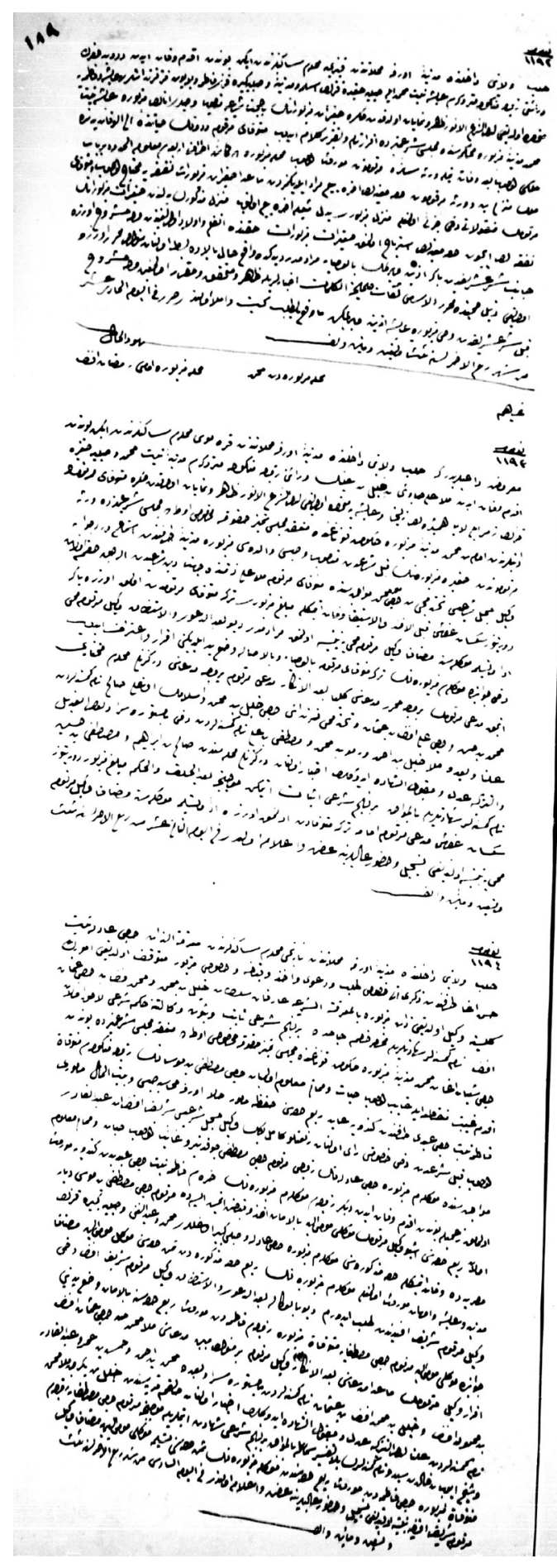

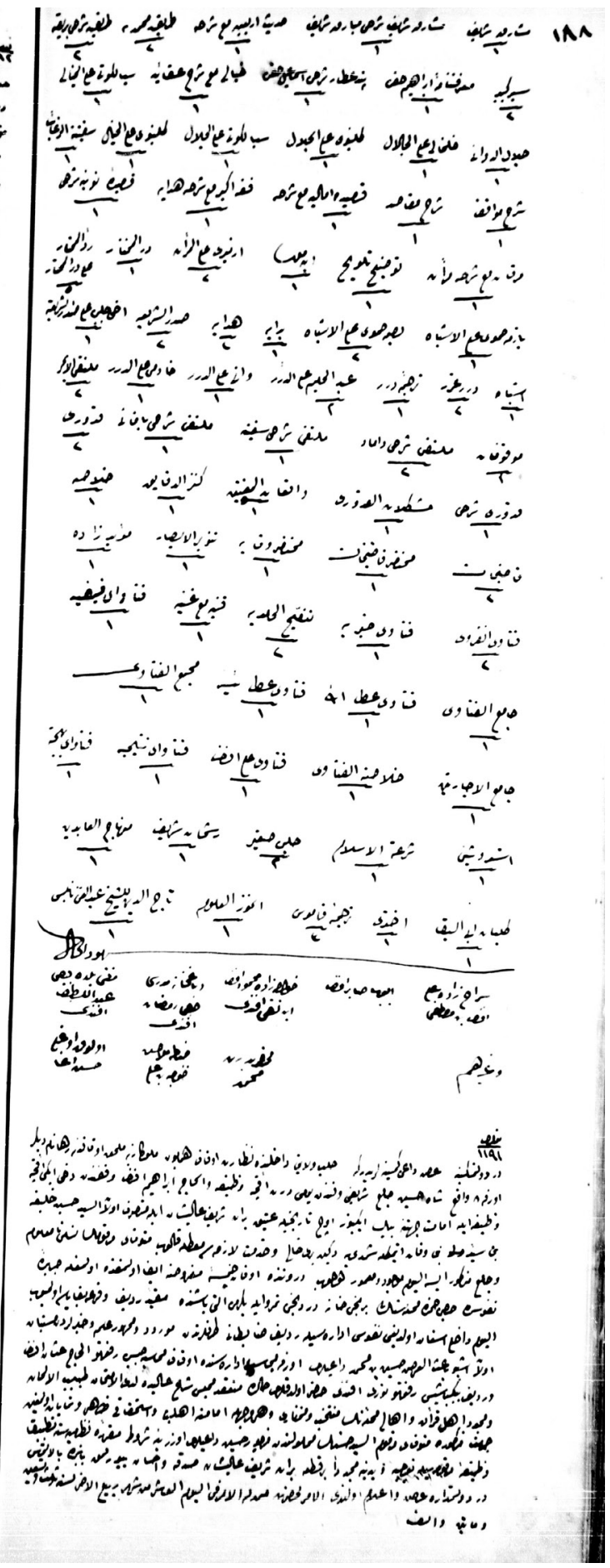


Hacı Kurra Efendizâde Mehmed Halid ve Mehmed Salih Efendilerin h.1293/1876 Tarihli Vakfiyesi'nde Yer Alan Kitapların Listesi (UŞS, nr. 211: 1190).

\begin{tabular}{|c|c|}
\hline Kitap Adı & Adeti \\
\hline Kıraât-ı Seb`a Üzerine Secaventli Mushaf-ı Şerîf & $1 \mathrm{kita}$ \\
\hline Delâil-i Şerîf ma‘a Hisnu’l-Hasîn & 1 cilt \\
\hline Delâil Şerhi Kara Davud & 1 cilt \\
\hline Kadı Beyzavî & 1adet \\
\hline Tefsîr-i Keşşaf & 1 cilt \\
\hline Tefsîr-i Malimü’t- Tenzîl & 1 cilt \\
\hline Tefsîr-i Tibyân & 1 cilt \\
\hline Sinaniye Tefsîri & $1 \mathrm{kıta}$ \\
\hline Sure-i Rahman... & 1 cilt \\
\hline Mevize-i İsmail Hakkı & 1 cilt \\
\hline Mevize-i Hasene & 1 cilt \\
\hline Dürretü’n-Nâsihîn & 1 cilt \\
\hline Riyadü'l-Cenne & 1 cilt \\
\hline Tezkere & 1 adet \\
\hline Dürretü'l-Vaizin & 1 adet \\
\hline Neşru'l-Kebîr & 2 adet \\
\hline Tefsîr-i Ebu'l- Leys & 1 adet \\
\hline Vücuhdan Zubde Şerhi & 1 adet \\
\hline Şatıbî & 1 adet \\
\hline Şatıbî Şerhi & 1 adet \\
\hline Dürer & 2 adet \\
\hline Dürer Şerhi & 1 adet \\
\hline ma'a şerhihi & 1 adet \\
\hline Mecmau'I-Fevâidli Şeyhi'I-Mağribi & 1 adet \\
\hline Câmiu's- Sağîr Şehi Menar & 1 adet \\
\hline Şifâ-ı Şerîf Şerhi Aliyu'I-Kârî & 2 adet \\
\hline Meşârik-i Şerîf & 1 adet \\
\hline Meşârik-i Şerîf Şerhi Mebarik-i Şerîf & 1 adet \\
\hline Hadîs-i Erbain ma’a Şerhihi & 1 adet \\
\hline Tarîkat-ı Muhammediye & 2 adet \\
\hline Tarîkat-ı Şerhi Berika & 2 adet \\
\hline Siyer-i Kebîr & 2 adet \\
\hline Marifetnâme-i İbrahim Hakkı & 1 adet \\
\hline Pend-i Attar Şerhi İsmail Hakkı & 1 adet \\
\hline Hayâlî ma‘a Şerhi Akâid & 1 adet \\
\hline Silekuti ale'l-Hayâlî & 1 adet \\
\hline Celâl e'd-Devvanî & 1 adet \\
\hline
\end{tabular}




\begin{tabular}{|c|c|}
\hline Kitap Adı & Adeti \\
\hline Hallali ale'l-Celâl & 1 adet \\
\hline Gelenbevî ale'l- Celâl & 1 adet \\
\hline Silekuti ale'I-Celâl & 1 adet \\
\hline Gelenbevî ale'l- Hayal & 1 adet \\
\hline Sefînetu'r-Reğayib & 1 adet \\
\hline Şerhi Mevâkıf & 1 adet \\
\hline Şerhi Mekasıd & 1 adet \\
\hline Kasîde-i Emaliye ma‘a Şerhihi & 1 adet \\
\hline Fıkh-ı Ekber ma’a Şehihi Hidaye & 1 adet \\
\hline Kasîde-i Nuniye Şerhi & 1 adet \\
\hline Mirkât ma'a Şerhihi Mir'ât & 1 adet \\
\hline Tandih-i Telvih & 1 adet \\
\hline İbn-i Melek & 1 adet \\
\hline İzmirî ale'l- Mir'ât & 2 adet \\
\hline Dürrü'l- Muhtâr & 1 adet \\
\hline Reddü’l- Muhtâr alâ Dürül Muhtâr & 5 adet \\
\hline Yazma Hamavî ale'l- Eşba & 1 adet \\
\hline Basma Hamavî ale'I-Eşba & 2 adet \\
\hline Bidâye & 1 adet \\
\hline Hidaye & 2 adet \\
\hline Sadru'ş-Şeria & 2 adet \\
\hline Ahi Çelebi alâ-Sadri'ş-Şeria & 1 adet \\
\hline Eşbah & 1 adet \\
\hline Dürer-i Gurer & 2 adet \\
\hline Tercüme-i Dürer & 1 adet \\
\hline Abdulhalim ale'd-Dürer & 2 adet \\
\hline Vanîale'd-Dürer & 1 adet \\
\hline Hadimîale'd-Dürer & 1 adet \\
\hline Mülteka'l Ebhur & 2 adet \\
\hline Mevkûfât & 1 adet \\
\hline Mülteka Şerhi Dâmâd & 2 adet \\
\hline Mülteka Şerhi Sefine & 1 adet \\
\hline Mülteka Şerhi Bağanî & 1 adet \\
\hline Kudûrî & 2 adet \\
\hline Kudûrî Şerhi & 1 adet \\
\hline Müşkilat'I-Kudûrî & 1 adet \\
\hline Vâkıâtu'I-Müftîn & 1 adet \\
\hline Kenzu'd-Dekâik & 1 adet \\
\hline Hulâsa & 1 adet \\
\hline
\end{tabular}




\begin{tabular}{|l|c|}
\hline Kitap Adı & Adeti \\
\hline Kadıhan & 2 adet \\
\hline Muhtasar-ı Kadıhan & 1 adet \\
\hline Muhtasar-ı Vikaye & 1 adet \\
\hline Tenviru'I-Ebsar & 1 adet \\
\hline Müeyyedzâde & 1 adet \\
\hline Fetâvâ-yı Ankaravî & 2 adet \\
\hline Fetâvâ-yı Hayriye & 1 adet \\
\hline Tenkihu'I-Hamidiye & 2 adet \\
\hline Kunye ma'a Gunye & 1 adet \\
\hline Fetâvâ-yı Feyziye & 1 adet \\
\hline Câmi'u'I-Fetâvâ & 1 adet \\
\hline Hulasetu'I-Fetâvâ & 1 adet \\
\hline Fetâvâ-yı Ali Efendi & 1 adet \\
\hline Fetâvâ-yı Netice & 1 adet \\
\hline Fetâvâ-yı Behcet & 1 adet \\
\hline Eşduşî & 1 adet \\
\hline Şir'atu'I-İ̀lâm & 1 adet \\
\hline Haleb-i Sağîr & 2 adet \\
\hline Reşehat-ı Şerîf & 1 adet \\
\hline Minhâcu'I-Abidin & 1 adet \\
\hline Külliyât-ı Ebi'I-Beka & 1 adet \\
\hline Ahterî & 1 adet \\
\hline Terceme-i Kâmûs & 3 adet \\
\hline En-Muzu'I-Ulûm & 1 adet \\
\hline Taceddinli'ş-Şeyh Abdulgani Nabulsi & 1 adet \\
\hline
\end{tabular}


